\title{
Non-consensual sexual experiences of young people: A review of the evidence from developing countries
}

Shireen J. Jejeebhoy

Population Council

Sarah Bott

Follow this and additional works at: https://knowledgecommons.popcouncil.org/departments_sbsr-rh

Part of the Demography, Population, and Ecology Commons, Domestic and Intimate Partner Violence Commons, Family, Life Course, and Society Commons, and the International Public Health Commons How does access to this work benefit you? Let us know!

\section{Recommended Citation}

Jejeebhoy, Shireen J. and Sarah Bott. 2003. "Non-consensual sexual experiences of young people: A review of the evidence from developing countries," South \& East Asia Regional Working Paper no. 16. New Delhi: Population Council. 


\section{South \& East Asia}

Non-consensual

sexual experiences of young people:

\section{A review of the evidence from developing countries}

Shireen J Jejeebhoy Sarah Bott

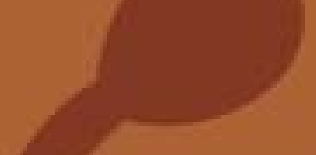




\section{Non-consensual sexual}

experiences of young people: A review of the evidence from developing countries

Shireen J Jejeebhoy

Population Council, New Delhi, India

\section{Sarah Bott}

Independent Consultant, Los Angeles, USA 



\section{Contents}

List of Tables and Figures $\quad$ iv

Abstract $\quad v$

Acknowledgements vi vi vi vis

1. Introduction 1

2. Defining and operationalising sexual coercion 2

3. Data sources and limitations 5

4. The context of non-consensual sexual 6

experiences among young people
$4.1 \quad$ Forced penetrative premarital or extramarital

$\begin{array}{lll}4.1 & \text { Forced penetrative premarital or extramarital } & 6\end{array}$

sex among girls and young women
Forced sex within marriage

4.2 Forced sex within marriage $r$

4.3 Forced penetrative premarital or extramarital 10

$\begin{array}{ll}\text { sex among boys and young men } & 11 \\ \text { Attempted rape, unwanted touch or } & 11\end{array}$

4.4 Attempted rape, unwanted touch or
fondling/molestation

$\begin{array}{ll}\text { 4.5 Exchange or transactional sex } & 13\end{array}$

$\begin{array}{ll}\text { 4.6 Sexual coercion in educational settings } & 15\end{array}$

5. Perpetrators of non-consensual experiences 16

$\begin{array}{lll}5.1 & \text { Strangers } & 16\end{array}$

$\begin{array}{ll}5.2 & \text { Peers and intimate partners } \\ 5.3 & 16\end{array}$

$\begin{array}{lll}5.3 & \text { Authority figures } & 17\end{array}$

6. Adverse consequences of forced sex and 18

other forms of sexual coercion

7. What are the underlying risk factors? 20

7.1 Gender double standards and lack of awareness of rights 20

7.2 Inadequate communication and the inability to 23

negotiate on sexual matters

7.3 Lack of supportive family and peer environments on sexual 24

health matters

8. Responses to and by the victim 26

8.1 Response of young persons who experience coercion 26

8.2 Response of family members, friends and 26

community members

8.3 Response of the health sector and law enforcement agencies 27

9. Summary and key recommendations 28

$\begin{array}{lll}9.1 & \text { Programme recommendations } & 28\end{array}$

$\begin{array}{lll}9.2 & \text { Research recommendations } & 30\end{array}$

References $\quad 32$

Appendices 38 


\section{List of Tables and Figures}

Table 1: Forms and contexts of non-consensual sex as 3 experienced by young people in developing countries

Figure 1: Young people's experience of forced sexual relations by region and study

Figure 2: Young people's experience of first sex by region and study

Figure 3: Young people's experiences of a range of unwanted sexual acts by region and setting

Figure 4: Role of perceived parental support in protecting adolescents from forced sex, Goa, India

\section{Appendix Tables}

Table 1: Magnitude of lifetime experience of forced sexual relations in adolescence among young females:

Findings from surveys

Table 2: Experience of forced first sex among young females:

Findings from various surveys

Table 3: Experience of forced sexual relations among

sexually active, pregnant young females or recent mothers: Findings from various surveys

Table 4: Magnitude of experience of forced sexual

relations (life-time or at initiation) in

adolescence among young males:

findings from various surveys 


\section{Abstract}

Although there is increasing evidence of risky consensual sex among young people in developing countries, non-consensual sexual experiences among them have rarely been studied and few interventions have been designed to protect them from the risks of such experiences. However, what is available suggests that coercion and unwantedness may play a considerable role in the sexual relations of young people — girls and young women but also boys and young men. The implications of non-consensual sexual experiences for young people's rights, their health and development and the risks they pose in the transition to adulthood are enormous. This review collates what is known about non-consensual sexual experiences of young people - those aged 10-24 - in developing countries, synthesises from this a profile of the magnitude and correlates of sexual coercion, and draws lessons for the implementation of appropriate programmes. Notwithstanding significant methodological limitations, the few available studies provide several common insights and have suggested that although definitions, study populations and study designs may differ, making comparison difficult, nonconsensual sex is indeed experienced by disturbing proportions of young people in all settings from which data were drawn. Non-consensual sex is experienced largely by girls and women, but also by boys and men. While studied largely among the unmarried, there is evidence that it is commonplace among married couples as well. It occurs largely among individuals who are acquainted with each other. It covers a continuum of behaviours ranging from unwanted verbal advances to unwanted touch to assault and forced sex, as well as sex in exchange for money, gifts, food or protection. The consequences of sexual coercion are formidable: they are short and long-term; and have physical, psychological and social effects. Sexual health manifestations range from unintended pregnancy, abortion and infection to risk-taking behaviours, including early onset of consensual sex, multiple partner relations and non-use of condoms. Psychological outcomes range from symptoms of anxiety and depression to suicide attempts. School performance can also be affected. A number of obstacles inhibit adolescents from protecting themselves from non-consensual sexual relations and from taking action against a perpetrator or to withdraw from a coercive relationship. Gender double standards and expectations of women and men in the sexual arena dominate these obstacles. Communication and negotiation on sexual matters, moreover, tend to be difficult and are often replaced by actions that include force and violence to resolve differences. The lack of a supportive environment and trusted adults and peers to consult on sexual health matters may also enhance young people's (and particularly young women's) vulnerability to coercive sexual relations. And finally, perceptions of institutional indifference - at the community, school, crime and health sector levels - can inhibit help-seeking both among victims as well as others who may wish to seek counselling on how to confront a potentially threatening situation. We conclude with a discussion of programmatic and research priorities. 


\section{Acknowledgements}

We are grateful to Marge Berer, Annabel Erulkar, Deepika Ganju, Philip Guest, K.G. Santhya, Iqbal Shah, Ina Warriner, Vijaya Nidadavolu, Komal Saxena and Anjali Widge for their valuable suggestions and assistance.

\section{Caveat}

Information is, happily, in a state of fluidity. Since writing the original draft of this paper, new information and data have been published and have shed new light on non-consensual experiences of young people. As far as possible we have tried to update the paper, but we recognise that there will always be gaps, and perhaps whole areas of importance that we have failed to address. We would be grateful for any further relevant information that anyone reading this Working Paper is able to provide us with, and we will try to incorporate it into our next publication. 


\section{Introduction}

Although there is increasing evidence of risky consensual sex among young people in developing countries, non-consensual sexual experiences among them have rarely been studied and few interventions have been designed to protect young people from the risks of such experiences. At the same time, anecdotal evidence, crime data and findings from small case studies present a disturbing picture of coerced or unwanted sex and sexual touch among significant numbers of young people, particularly girls but also boys and young men. While rape is the most extreme form of non-consensual sex, case studies in diverse socio-cultural settings have documented a broad range of experiences that can be identified as sexual coercion, including unwanted touch, coerced sex through threats, and sex in exchange for gifts and money. For many young people, sexual initiation during childhood or adolescence was coerced. Indeed, the evidence suggests that coercion and unwantedness may play a considerable role in the sexual relations of young people — girls and young women as well as boys and young men.

While evidence suggests that sexual coercion may occur at any age, the circumstances of young people's lives and the resources at their disposal are quite different from those of adults, requiring a specific focus on their experiences and needs. Under certain circumstances, and particularly at the time of first sexual experience, young people may be less equipped than adults to avoid non-consensual sex and may have fewer choices available to them when they do experience coercion.

Moreover, the implications of non-consensual sexual experiences for young people's rights, their health and development, and the risks they pose in the transition to adulthood are enormous. For example, adolescents who are sexually violated are identified as a sub-group with an especially high risk of HIV (see UNICEF/ UNAIDS/WHO 2002; WHO 2002). The objective of this review is to collate what is known about nonconsensual sexual experiences of young people - those aged 10-24 - in developing countries, synthesise from this a profile of the magnitude and correlates of sexual coercion, and draw lessons for the implementation of appropriate programmes to address these issues. 


\section{Defining and operationalising sexual coercion}

Sexual coercion has been defined in various ways, such as the:

act of forcing (or attempting to force) another individual through violence, threats, verbal insistence, deception, cultural expectations or economic circumstances to engage in sexual behaviour against her/his will. As such, it includes a wide range of behaviours from violent forcible rape to more contested areas that require young women to marry and sexually service men not of their choosing. The touchstone of coercion is an individual woman's lack of choice to pursue other options without severe social and physical consequence. (Heise, Moore and Toubia 1995)

The recent World Report on Violence and Health (WHO 2002) reinforces this definition, and defines sexual violence as:

any sexual act, attempt to obtain a sexual act, unwanted sexual comments or advances, or acts to traffic, or otherwise, directed against a person's sexuality using coercion, by any person regardless of their relationship to the victim.

Both definitions acknowledge that non-consensual sexual experience exists along a continuum of behaviours, from threats and intimidation to unwanted touch to rape, and that the victim lacks choices that do not have severe physical and social consequences.

Drawing from these definitions and from insights of available research, we have attempted to classify the diverse experiences that young people in developing countries have identified as non-consensual (see Table 1).

Trafficking, forced prostitution and forced sex in situations of conflict are significant aspects of non-consensual sexual experiences among young people; however, we have opted to exclude them here in order to focus on those forms experienced more generally by young people in developing countries. These include forced premarital or extramarital sex, marital rape, exchange or transactional sex, as well as attempted rape, unwanted touch, fondling or molestation.

Available studies have used different methods to define and measure coercion, and there is often ambiguity in definitions and interpretation. It is difficult to discern from existing studies how inclusively questions on forced sexual relations were framed. Most surveys that report on this topic ask a fairly general question, usually on the lines of "have you ever been forced to engage in sex?" Others have measured forced sexual relations by asking questions concerning respondents' motives for engaging in sexual relations, and estimating the number who responded that sex "was forced". Increasingly, research has begun to look at the circumstances of sexual initiation. Typically the question is posed as follows: "Your first sexual experience, was it something that you wanted at that time, something that you agreed to but did not want, or something that you were forced to do against your will?"

A limitation of these operational definitions is that young people engaging in transactional sexual relations, or those who acquiesce under pressure to a partner's demands for sex as an expression of commitment, may not respond in the affirmative to a general question on "forced" sex. Indeed, few studies in developing countries 
Table 1 : Forms and contexts of non-consensual sex as experienced by young people in developing countries

\begin{tabular}{|c|c|c|}
\hline Context & Perpetrator & Form \\
\hline $\begin{array}{l}\text { Forced sex within marriage/ } \\
\text { formal union }\end{array}$ & Husband/formal partner & $\begin{array}{l}\text { Physical force } \\
\text { Threats and intimidation, } \\
\text { including threats of physical } \\
\text { violence, abandonment, } \\
\text { withholding economic support }\end{array}$ \\
\hline $\begin{array}{l}\text { Forced penetrative premarital or } \\
\text { extramarital sex } \\
\text { (can include oral, anal or vaginal } \\
\text { penetration) }\end{array}$ & $\begin{array}{l}\text { Peer, } \\
\text { Partner } \\
\text { Family member } \\
\text { Figure of authority, } \\
\text { including teacher, boss } \\
\text { Acquaintance } \\
\text { Stranger }\end{array}$ & $\begin{array}{l}\text { Physical force } \\
\text { Threats and intimidation } \\
\text { Emotional manipulation/abuse } \\
\text { Deception } \\
\text { Blackmail }\end{array}$ \\
\hline $\begin{array}{l}\text { Attempted rape } \\
\text { Unwanted touch or fondling/ } \\
\text { molestation } \\
\text { Non-contact forms of abuse } \\
\text { such as verbal harassment, } \\
\text { forced viewing of pornography, } \\
\text { flashing, etc. }\end{array}$ & $\begin{array}{l}\text { Peer } \\
\text { Partner/husband } \\
\text { Family member } \\
\text { Figure of authority, } \\
\text { including teacher, boss } \\
\text { Acquaintance } \\
\text { Stranger }\end{array}$ & $\begin{array}{l}\text { Physical force } \\
\text { Threats and intimidation } \\
\text { Deception } \\
\text { Blackmail }\end{array}$ \\
\hline Exchange or transactional sex & $\begin{array}{l}\text { Substantially older partners } \\
\text { ("sugar daddy," "aunty," } \\
\text { "sugar mummy") } \\
\text { Peer }\end{array}$ & $\begin{array}{l}\text { Economic incentives, } \\
\text { particularly in the context of } \\
\text { extreme poverty }\end{array}$ \\
\hline Trafficking, forced prostitution & Third party & $\begin{array}{l}\text { Organised movement of people, } \\
\text { usually women, between } \\
\text { countries and within countries } \\
\text { for sex work (sometimes } \\
\text { promising economic } \\
\text { opportunity) } \\
\text { Physical force, threats and } \\
\text { intimidation }\end{array}$ \\
\hline Rape in conflict situations & Combatant & $\begin{array}{l}\text { Physical force and threats of } \\
\text { violence }\end{array}$ \\
\hline
\end{tabular}

Note: This classification is merely illustrative and these categories are not always mutually exclusive. 
have explored young people's own terminologies and definitions of non-consensual sexual relations. (In contrast, there is a growing body of research in the US on such issues as "dating violence" among adolescents, and child abuse survivors.)

A rare qualitative study in Nigeria (Ajuwon et al. 2001b) of young people's perceptions of coercion reports considerable diversity in responses, which highlight the ambiguities in the definitions mentioned above. In this study, young people drew up lists of coercive behaviours, which included actual manifestations of force (from threats to unwanted touch to rape) as well as actions that went beyond the actual event. For example, boys and young men listed actions that they recognised as an integral part of preparing or plotting coercion such as forcing girls to watch pornographic films, drugging them or putting a spell on them. Girls and young women listed forced abortion in the case of unwanted pregnancy, forced pregnancy and non-use of condoms or contraception. Despite these broad definitions, however, when asked to narrate and role-play coercive incidents, young people overwhelmingly depicted scenes of rape.

In a case study in South Africa, girls tended to associate the concept of rape only with the actions of strangers or groups of men rather than those of a peer or boyfriend (Jewkes et al. 2002; Wood and Jewkes 2001; Wood, Maforah and Jewkes 1996; 1998). This study of 24 Xhosa adolescents seeking antenatal care in South Africa reports that adolescents' narratives suggested the experience of a continuum of force, from male "pleading" and "persuading" to assault. Similarly, girls in Mbale district, Uganda, articulate a range of non-consensual behaviours, from emotional pressure to physical force, with which they are familiar, including "being strongly convinced [emotional pressure]," to "boys trying to grope you," to "abuse from boys," to "rape" (Hulton, Cullen and Khalokho 2000). 


\section{Data sources and limitations}

Although there is a growing body of research on sexual abuse and coercion among adolescents in developed countries, such as the US and Great Britain (for concise reviews of the US literature, see NCIPC 2000a; 2000b; 2003; for a large archive of US government statistics and research articles, see RAINN n.d.), fewer studies on this issue have been carried out in developing countries. Before reviewing the available evidence on different types of sexual coercion, limitations of existing data will be discussed.

First, as the World Health Organisation's World Report on Violence and Health emphasises, much sexual violence remains undisclosed because of shame, blame and other factors (WHO 2002). Therefore, the extent of sexual violence as revealed in police reports is no more than the tip of the iceberg. Surveys and other investigations are better placed to reveal experiences of coercion. In this overview, we restrict ourselves to evidence obtained from three kinds of studies: school- or community-based surveys, facility-based surveys (typically among survivors of sexual violence or coercion who have sought health care) and qualitative studies. We have cast as wide a net as possible — searching the literature from different developing regions and focusing on relevant published and unpublished studies. Evidence was culled from several types of studies. These include the few studies that were specifically designed to explore non-consensual experiences among young people, as well as those intended to explore the nature of adolescent sexual partnerships more generally. Large or community-based quantitative investigations are rare, however. Only recently has there been an attempt to incorporate questions on the "wantedness" of sexual initiation in studies of sexual and reproductive health of young people. For example, the Demographic and Health Survey has incorporated questions on the circumstances of first sex in modules on adolescent sexual experiences in some settings, and among women in general in others (INEC, MINSA 2001). It is noteworthy that these data have not been widely explored or published, but they represent a future source of important information on the topic.

The available evidence is unevenly distributed and tends to be skewed towards the experience of girls rather than boys. It tends to omit the experiences of married young people. It comes from a few countries in each region and may well distort the picture of non-consensual sexual experiences among youth more generally. Indeed, the largest number of studies from any one country are from South Africa, increasingly acknowledged as a special case of the negative consequences of social upheaval. In addition, there is a particular dearth of research evidence on the nature and patterns of forced sexual relations in the context of trafficking, forced prostitution and situations of conflict.

Moreover, the evidence presented here comes from a heterogeneous set of studies, which presents problems of generalisability and comparability. Studies thus far have been small and rarely drawn from community-based samples. Most draw their samples from special sub-groups, for example, students from school-based populations, apprentices and factory workers in selected work places, or pregnant young women attending antenatal clinics or those attending health facilities for reproductive health or other problems. The age range of samples also vary considerably. Most studies have focused on young people aged 10-24; however in a few cases, reports are drawn retrospectively from populationbased samples of young people aged 15 and above. As noted earlier, studies have measured sexual coercion in different ways; some have focused on the more extreme forms of forced sexual experiences such as rape, while others have explored sexual coercion involving threats, deception, pressure or exchange, as well as other forms of harassment.

Another limitation of the existing data is the reliability of young people's responses on a topic as sensitive as sexual relations and force. It is possible that traumatic events such as sexual abuse will be under-reported to interviewers who have not built adequate rapport with respondents. Fear of stigma and shame among girls as well as boys may also lead them to under-report a coercive experience. In contrast, in some settings, adolescent girls may report a consensual encounter as undesired because of sexual double standards that condone premarital sex among boys but not girls. The consequences of each of these influences on reported experiences of sexual coercion may vary across cultures, as well as between girls and boys, making comparisons difficult. 


\section{The context of non-consensual sexual experiences among young people}

It is important to note that the legal and socio-cultural contexts in which adolescent partnerships occur more generally vary greatly between and within different countries and regions. In many settings women have fewer rights than men, and limited rights within marriage, either as a matter of law or practice (see Human Rights Watch 2002b). For example, not all countries have legislation that gives women the right to refuse a forced marriage, recognises (and penalises) marital rape, or gives women the same rights to divorce as men (CRLP 2002).

There is great diversity across developing countries in terms of the age at which young females and males marry, the extent to which society allows adolescent girls and boys to interact socially, and attitudes towards out-of-wedlock sexual activity and pregnancy among the unwed. For example, in many settings, pregnancy precedes formal marriage among significant proportions of young women; in others, it rarely does. So also there is diversity in the autonomy, legal rights and social status of girls and young women compared to their male counterparts.

Nonetheless, evidence suggests that regardless of the social and legal context, young women and girls - and even young males - experience coercive sex in all settings, and no society appears to be exempt (WHO 2002).

\subsection{Forced penetrative premarital or extramarital sex among girls and young women}

Studies that have inquired about forced sexual relations among youth are marked by considerable lack of uniformity in questions posed and study populations covered. However, as illustrated in Figure 1 and summarised in Appendix Table 1, findings reiterate that despite wide variations by site, considerable proportions have experienced forced sexual relations - between 2 per cent and 20 per cent of adolescents and young women typically report the experience of forced sexual relations over the course of their lifetime. The findings of a nation-wide school-based study in the US are relatively similar and worth noting: 7 per cent of younger and 12 per cent of older school girls reported an experience of sexual abuse or sex against their will (Schoen et al. 1997). The possibility of under-reporting cannot be overlooked: for example, in a study of high school girls in Ethiopia, the wide difference between the percentage who reported the experience of rape and those who reported knowing a girl who had experienced rape ( 5 and 38 per cent) may have been due in part to underreporting of experiences (Mulugeta, Kassaye and Berhane 1998).

In studies of first sex (among those who have ever engaged in sexual relations), some 15-30 per cent typically report that the experience was forced (see Figure 2 and Appendix Table 2). For large proportions, initiation occurred as a result of "cheating" or "pressure" from a partner. For example, 39 per cent of sexually active high school female students in Korea, and three of 11 sexually active rural female adolescents in north and north-east Thailand report that first sex was the result of force or pressure from their partner (Isarabhakdi 1995; Kim 1998). While evidence from developing countries is relatively sparse, that from such settings as the US and New Zealand suggests that the earlier the sexual initiation among girls, the more likely it was to have been forced (see for example, Heise, Ellsberg and Gottemoeller 1999). 
FIGURE 1: Young people's experience of forced sexual relations by region and study

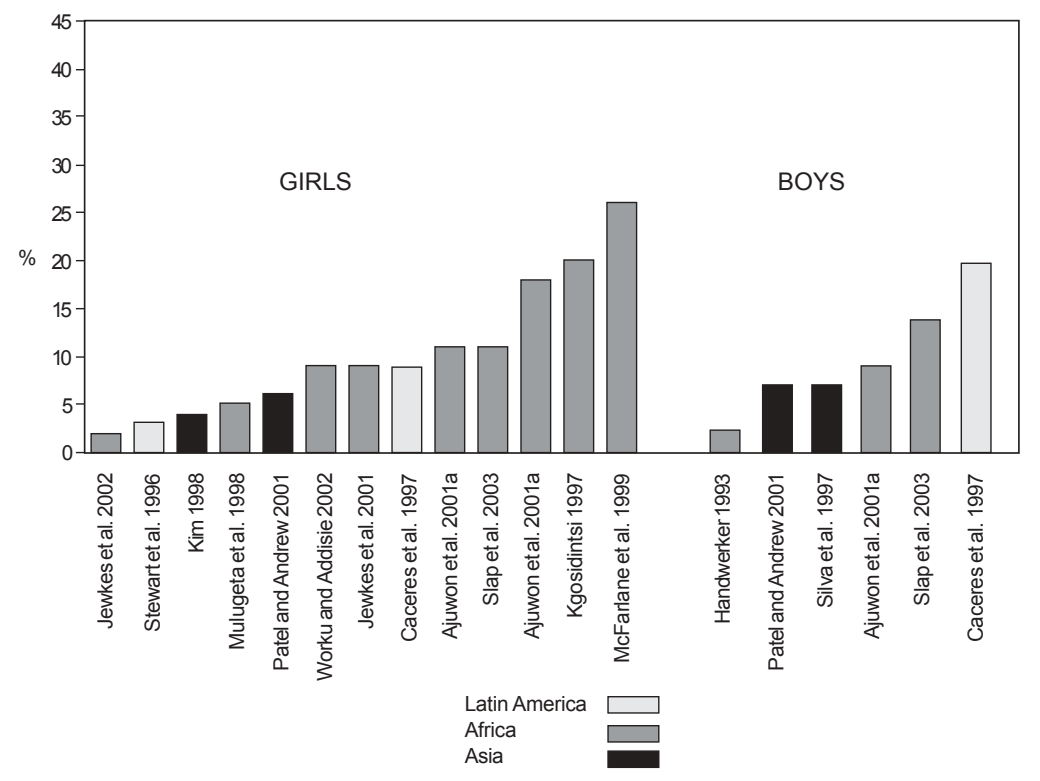

FIGURE 2: Young people's experience of first sex by region and study

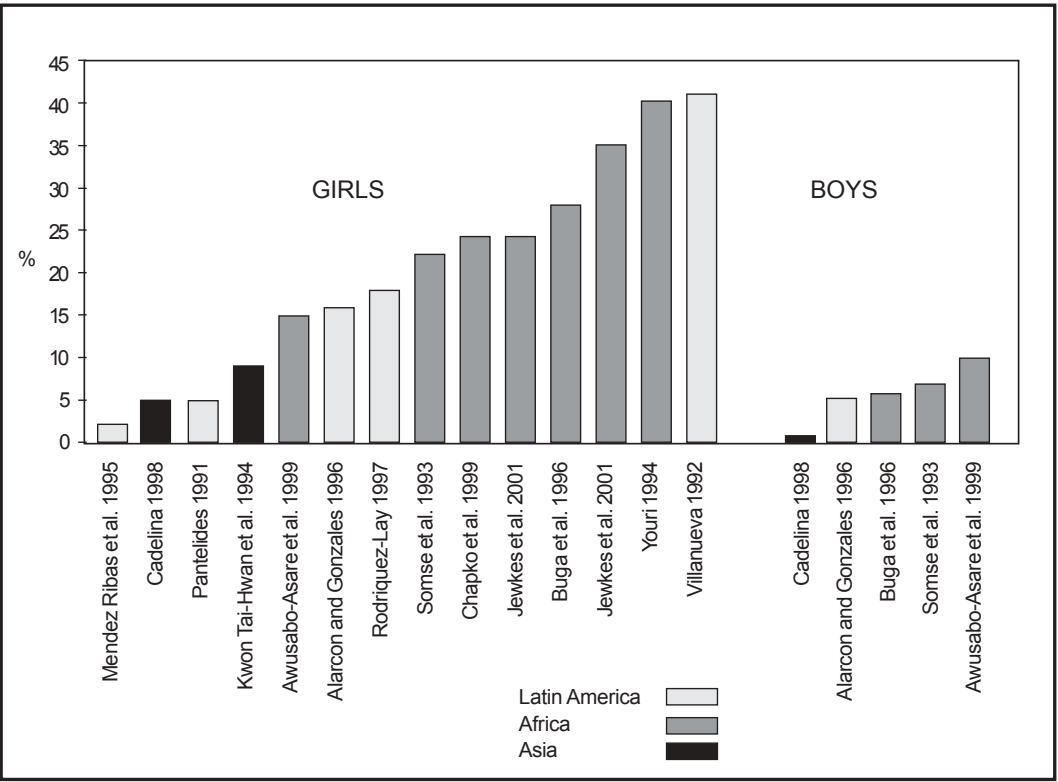


Some studies have presented findings on the experience of forced sexual relations among sexually active, or among ever pregnant youth sub-populations, either through community- or facility-based investigations (see Appendix Table 3). For obvious reasons, the proportion of respondents reporting a coercive experience in facility-based studies would be higher than among youth more generally. Similarly, studies of victims of sexual violence suggest that a substantial proportion are young. For example, a study of survivors of sexual violence who sought care from the Centre for Care of Intra-familial and Sexual Violence in Mexico City reports that 50 per cent of its clients over the period 1990-96 were adolescents (Billings et al. 2002).

Qualitative studies from developing countries illustrate the circumstances under which forced sex occurs in different settings. Several similarities are evident. For example, non-consensual sexual events are most likely to occur in familiar settings (such as the neighbourhood, home or school), in the course of routine activities, and are largely perpetrated by those with whom the young person is acquainted (see for example, Ajuwon et al., 2001a; 2001b; Anonymous, 2000; Brown et al. 2001; Patel and Andrew 2001; Stewart et al. 1996). In a study using repeated peer focus group discussions with boys and girls aged 12-19 in Mpigi district, Uganda, adolescents acknowledged that chores that bring young people together — such as fetching water from a well or wood from the forest - in places far away from their homes, offer a convenient and "safe" location for rape; indeed, several, including those as young as 12-13 years reported witnessing a sister or acquaintance being raped (Bohmer and Kirumira 1997). In a qualitative study with in-depth interviews of 71 adolescents residing in a Delhi slum, similarly, girls reported some 32 separate instances of sexual coercion that involved a physical violation, verbal harassment or, more rarely, forced sexual initiation (Sodhi and Verma 2003).

Partner pressure is a significant factor underlying young people's acquiescence to sexual relations. For example, studies report that young girls experience pressure from their male partners to engage in sex for fear of rejection and abandonment, or withholding of money, rewards or even marks (in cases of sexual coercion of students by teachers). An in-depth case study of adolescent girls aged 14-18 who sought antenatal care in a facility in South Africa reveals that several girls reported forced sexual initiation: they described being deceived or forced into sex, and explained how they had acquiesced when attempts to resist were met with intimidation, threats or assault (Wood and Jewkes 2001; Wood, Maforah and Jewkes 1996; 1998). In India, adolescent girls residing in slum settings also reported being pressured into engaging in sexual relations by young men (Sodhi and Verma 2003).

It is also possible that the circumstances surrounding coercion vary among younger and older adolescents. For example, a qualitative study of adolescent girls in Kenya demonstrates that experiences differed even among adolescents aged only two years apart (Balmer et al. 1997). The youngest (aged 12-14) reported random incidents in which, typically, they were waylaid from performing a household chore on their way home and forced into sex. By age 16, girls reported more deliberately planned rapes by young men whose advances they were perceived to have rejected, and older adolescents reported the experience of non-consensual events perpetrated by, variously, boyfriends, peers and strangers. Moreover, notions of power were clearly evident. Even by age 16, young girls recognised that if they rejected the advances of boys, or were considered "haughty" and "in need of a lesson," that lesson would very likely involve humiliation through rape. In fact, older girls increasingly adopted a kind of resigned acceptance of rape. Older girls distinguished between three types of rape: that perpetrated by a boyfriend, "friendly rape" perpetrated by a friend or acquaintance, and rape by a complete stranger.

Several studies describe how male peers collude in plotting the timing and circumstances of coercive sex. They sometimes help to waylay or hold down the female victim or even participate in gang rape (see Ajuwon et al. 2001b; Sodhi and Verma 2003; Varga 2001).

Coercive incidents can also occur within the home and be perpetrated by a family member. For example in a qualitative study of 17-19-year-old adolescents in Mbale district of Uganda, adolescents described perpetrators to include peers, 
but equally "someone in your family — your father, your uncle" or "your father when he was drunk" (Hulton, Cullen and Khalokho 2000). A recent report by Human Rights Watch (2002a) on the links of sexual coercion and HIV risk among young girls in Zambia provides evidence from interviews with 100 girls drawn from various NGOs, orphanages and other institutions for youth suggesting that an alarming and possibly increasing number of abuses against young girls were perpetrated by family members - fathers, brothers, uncles, stepfathers and cousins. Families often colluded in hiding these abuses. Girls were often silenced and warned not to bring shame upon the family; in some cases they were threatened with physical abuse if they revealed the incident. Shame and stigma were pervasive and often the girl herself was blamed for inciting the incident. A study in Karachi, Pakistan reports, similarly, that rape by family members is not unknown; according to an adolescent victim: "How can I trust anyone in the world when my uncle has raped me?" (United Nations ESCAP, Government of Japan, National Commission for Child Welfare and Development, Pakistan 2001).

\subsection{Forced sex within marriage}

Evidence suggests that substantial sexual coercion against women occurs within marriage. An analysis of over 50 population-based surveys found that approximately 10-50 per cent of adult women around the world reported having been physically assaulted by an intimate male partner (including their husbands) at some point in their lives. Studies that have explored sexual violence have found that sexual abuse is present in approximately one-third to half the cases of physical abuse by an intimate partner (Heise, Ellsberg and Gottemoeller 1999).

In many developing settings, notably South Asia and sub-Saharan Africa, early marriage of girls remains widespread. However, in the context of early marriage from a rights perspective, it has been pointed out that the right to free and full consent to a marriage is recognised in the 1948 Universal Declaration of Human Rights and in several subsequent instruments on human rights (UNICEF 2001). It is important to note that arranged marriage is not synonymous with forced marriage. Within the rights framework used by UNICEF, for example, a young person of sufficient maturity can give (or refuse) consent to an arranged marriage. In fact, a collection of studies from South Asia found that in many settings, adolescents strongly supported the idea that their parents should decide whom they are to marry (Bott and Jejeebhoy 2003). However, the Universal Declaration of Human Rights argues that consent cannot be 'free and full' if at least one partner is very immature, and in many settings, young people — particularly young girls — are often forced to marry and consummate the marriage at a young age in the absence of informed consent (UNICEF 2001). In the Gambia, for example, a study reveals that 36 per cent of a sample of young wives had not been asked for their consent and did not know that they were to be married until the ceremony (Anonymous 1995).

A small body of research has begun to look at the circumstances surrounding the sexual experiences within marriage of girls who marry as young adolescents. Some of these studies highlight the extent to which marital sexual initiation is often characterised by force, fear and pain. For example, several studies from India, some reporting the retrospective experiences of adult women, reveal that early marital sexual experiences were typically traumatic, distasteful and painful, and often involved the use of physical force (George and Jaswal 1995 for Mumbai; Khan et al. 1996 for Uttar Pradesh; Sodhi and Verma 2003 for New Delhi). Excerpts from narratives of women from a study in a low-income urban setting in Delhi, India and among abortion-seekers in rural Uttar Pradesh support this evidence. One respondent described her sister's wedding night thus:

... she did not want to celebrate [the] first night but her husband was annoyed... he didn't agree and did it forcefully. She was having a lot of pain so her bhabhi [sister-in-law] took her to the dispensary the next morning." (18-year-old girl; Sodhi and Verma 2003)

Recounting her first sexual experience with her husband at age 13, one woman said:

It was a terrifying experience; when I tried to resist, he pinned my arms above my head. It must have been so painful and suffocating that I fainted. (32-year-old woman; Khan et al. 1996) 
Non-consensual sexual experiences of young people: A review of the evidence from developing countries

The narratives of young males in these settings corroborate this sense of entitlement:

At night, I asked her to take off her clothes. She refused. When I asked her two-three times, she started crying. I made her keep quiet, and after that I took her clothes off and did my work. (19-year-old painter; Sodhi and Verma 2003)

Older women in this setting told girls to accept this situation as normal. According to one girl, they were told, "If you won't give him then he would force and you will have pain" (Sodhi and Verma 2003).

Although evidence of coercive relationships within marriage comes largely from selected settings, notably South Asia, the paucity of evidence from other settings should not be interpreted to suggest that these experiences cannot be generalised. For example, in Zimbabwe, a qualitative study of young women who were pregnant in adolescence reports:

I told my sisters-in-law that my husband had forced me into sex, but they told me that this is part of life. (Hof and Richters 1999)

In Rio de Janeiro and Sao Paolo, Brazil, women also reported similar experiences. For example, poor factory workers who married in adolescence recalled that early sexual relations with their husbands were violent, terrifying and painful:

I screamed. He said, "You have to do it." It was a sad bloodbath; the next day I couldn't even walk. (Goldstein 1994)

\subsection{Forced penetrative premarital or extramarital sex among boys and young men}

Evidence suggests that throughout the world, boys and young men also experience forced sexual relations, although they have received less research attention than young women. Appendix Table 4 summarises findings from available studies and suggests that the proportion of boys and men reporting forced sexual relations (less than 10 per cent) falls within a narrower range. A nationally representative survey of school-going adolescent boys in the US concludes, similarly, that 5 per cent had experienced forced penetrative sex (Schoen et al. 2001).

A few qualitative studies have investigated forced sexual relations among young males. In-depth interviews in a low-income setting in Delhi, India revealed instances where older boys forced 12- and 13-year-old boys to have anal sex. For example:

... older boys used to ask me for [anal sex]... At that time, we used to feel very bad, but after some time, we also started asking boys our age for anal sex. (16-year-old male)

... when we were young, we used to have anal sex with large numbers of boys... We all together used to go to the latrines. Whosoever we would see there, we used to snatch his container and f- him. We couldn't put it inside but used to touch it on the skin only. (19-year-old married male; Sodhi and Verma 2003)

Other studies have highlighted the experiences of street boys-a particularly vulnerable group of adolescent males. These studies depict young males as both victims and perpetrators (with young girls and boys, alone or in gangs), or involved in transactional sex with older males and females (see Barker 1993 for studies in the Philippines, Thailand, Colombia and Kenya; Raffaelli et al. 1993 for Belo Horizonte, Brazil; Ramakrishna, 
Karott and Srinivasa Murthy 2003 for India). For example, some 14 per cent of street boys interviewed in Belo Horizonte, Brazil, reported being paid for sex, many more said they received other material rewards in return for sex, and several reported rape and gang rape (Raffaelli et al. 1993). A study of street boys in Bangalore, India (Ramakrishna, Karott and Srinivasa Murthy 2003) reveals that large proportions of boys were initiated into sex at an early age, between 10 and 12 years, and most of these relationships were likely to have been nonconsensual. For example:

... older boys come and force us, when we refuse they beat us. They tell me that they will give money ... Initially when others "call" us we are afraid. They also did it from the back [anal sex]. Initially it was a little painful, but afterwards there was no pain. Now, I have no fear. (Ramakrishna, Karott and Srinivasa Murthy 2003)

Moreover, as many as 77 per cent of street boys in this study reported pleasure from "raping a girl"; and some 44 per cent mentioned forcing sex on drunk women sleeping on the street as pleasurable — indeed raping a girl ranked second only to engaging in consensual relations with a girl as a pleasurable sexual activity (Srinivasa Murthy and Karott 2003).

In a few studies, young males mention being coerced into sex by young females (see, for example, Ajuwon et al. 2001a for Nigeria; Marston 2003 for Mexico). In Ibadan, Nigeria for example, 20 of 38 adolescent males who reported the experience of forced sex and some two in five of those reporting unwanted touch said that it was a heterosexual contact (Ajuwon et al. 2001a). In in-depth interviews with 53 young men aged 16-22 in Mexico City, several young males reported that girls put pressure on them to have sex through such actions as undressing, touching and commenting on the young male's penis, or taunting their lack of virility (Marston 2003). In some instances, other more subtle forms of coercion are reported such as pressure on young boys to have sex by older, often married women, or peer pressure on boys and young men to engage in relations with sex workers.

\subsection{Attempted rape, unwanted touch or fondling/molestation}

Rape is only the tip of the iceberg, and significantly larger proportions of young people have suffered other non-penetrative manifestations of coercion. Studies suggest that among a significant proportion of adolescent girls who experience rape, it is not an isolated event but follows a series of coercive but non-penetrative actions (see Figure 3). For example, in-depth interviews in Ibadan, Nigeria with adolescent female students and apprentices who had been raped suggest in several instances that forced penetrative sex followed a sequence of increasingly violent incidents (Ajuwon et al. 2001a).

Fewer studies have explored forced non-penetrative sexual experiences among young people. The findings of five studies considered in this review — two of high-school girls in Ethiopia (Addis Ababa and Western Shoa; and Debark Town, respectively), students and apprentices aged 15-19 in Ibadan, Nigeria, school-going adolescents in Goa, India and nursing students in Malaysia - are illustrative (Figure 3). While these are derived from small studies that reflect the behaviours of specific sub-groups and are unrepresentative, findings demonstrate the extent to which focusing solely on forced sexual intercourse can obscure the full picture of non-consensual sexual experiences among young people. While under-reporting is likely in all the studies, it is evident that considerably larger proportions of adolescents have experienced unwanted sexual touch or verbal intimidation, harassment or threats, and "unsuccessful" attempts at being forced to engage in sexual relations, in all settings and among both females and males. Substantially smaller proportions reported the experience of attempted rape, and fewer reported non-consensual penetrative sex.

Evidence of unwanted sexual advances also comes from studies of adolescents seeking counselling in selected clinics in Colombia (PROFAMILIA) and Peru (INPPARES). A study of 227 young women exhibiting signs 
FIGURE 3: Young people's experiences of a range of unwanted sexual acts by region and setting

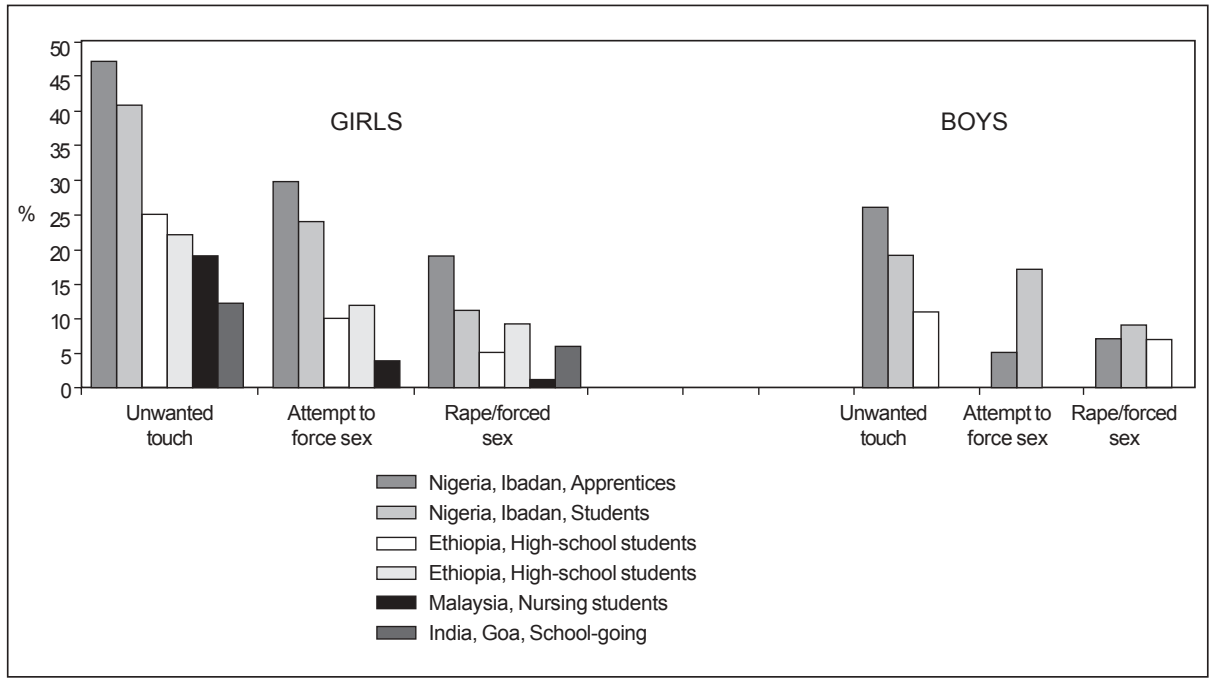

of sexual abuse reports that 68 per cent had been subjected to unwanted touch, mostly by a relative or friend, and for just under half of these, unwanted touch had been experienced from the age of 9-13 (Stewart et al. 1996).

Again, qualitative studies reinforce these findings of relatively widespread experience of unwanted touch. A school-based study in Kenya reports considerable sexual harassment and unwanted touch among students (Ajayi et al. 1997). In well over half of all primary schools and two-fifths of all secondary schools studied, researchers observed harassment of girls by boys; the reverse was rarely observed. That unwanted touch appeared widespread was revealed in focus group discussions of 15-19-year-old girls:

Boys come and hold our breasts in class even when the teacher is there; he pretends that he is packing something...

This abusive behaviour from boys happens everywhere, in the streets, in school, and in discos, and it is normally the boys we know in school and at home. (Ajayi et al. 1997)

A study of low-income adolescents in Delhi, India, reports a similar finding:

Once I was coming through the street... and this boy came from the front, pressed my breasts, and ran away. I had not wrapped a chunni [scarf, symbol of modesty]. (14-year-old girl; Sodhi and Verma 2003)

What is clear is that a succession of non-consensual but perhaps less painful experiences may precede rape; recognising that experiences occur on this continuum of behaviours offers a window of opportunity for prevention measures. 


\subsection{Exchange or transactional sex}

There is increasing evidence that youth — particularly young women — engage in sexual relations in exchange for money, clothing or school fees. A comparison of findings from Demographic and Health Surveys in several sub-Saharan African countries notes, for example, that 13 per cent of unmarried girls aged 15-19 had received money or gifts in exchange for sex in the four weeks preceding the survey; in Kenya, Mali and Zambia, as many as 21 per cent, 26 per cent and 38 per cent respectively reported such an experience over the 12 months preceding the survey (Population Reference Bureau 2000). It must be mentioned here that the questions in these surveys were ambiguously phrased as they did not distinguish between giving and receiving money or gifts in exchange for sex; it was assumed that girls who responded in the affirmative had received rather than given gifts or money. Moreover, not all exchange or transactional sex fits the typical definition of sexual coercion. There is often a fine line between culturally accepted gift giving in the context of sexual relations, and more coercive forms of exchange in which refusing the offer of financial support or gifts from another would entail severe consequences. Indeed, in several examples cited below, young people might not themselves view the exchange as a case of coercion. However, it is noteworthy that young people are often financially dependent on older adults, for example, in order to continue schooling or simply to survive. This power imbalance may make young people particularly vulnerable to sexual coercion in the form of exchange or transactional sex.

\section{- Exchange or transactional sex with substantially older partners}

Studies largely but not exclusively from sub-Saharan Africa describe the occurrence of sex in exchange for money, gifts and favours. The economic motivation for a relationship is especially obvious in the case of relationships with substantially older partners, also known as "sugar daddy" relationships, observed frequently among girls (Balmer et al. 1997; Brown et al. 2001 for Kenya; Fraser 2002 for Trinidad and Tobago; Meekers and Calves 1997 for Cameroon). A review of over 45 studies of cross-generational and transactional sexual relations in sub-Saharan Africa reports that engaging in sexual relations with older partners is the norm among adolescent girls in some settings (Luke 2003; Luke and Kurz 2002). In Botswana for example, girls as young as 13 years reported having engaged in sex with "sugar daddies," and one in five school-going and out-ofschool adolescent girls reported that it is difficult to refuse sex when money and gifts are offered (Kgosidintsi 1997). The recent Human Rights Watch report (2002a) of sexual abuse among girls in Zambia suggests that the HIV epidemic has resulted in strengthening the phenomenon of older men who, fearing infection among older adolescents, increasingly seek younger girls with whom to engage in sexual relations.

Facility-based studies illustrate the extent to which transactional relationships with older partners prevail (although findings of these studies are not generalisable, referring as they do to a specific subset of youth who have experienced a particular outcome [pregnancy, abortion or infection, for example] and have sought care for it). A facility-based study of pregnancy among unmarried adolescents in Nigeria suggests that partners of as many as 84 per cent of pregnant adolescents attending a maternity facility were older males, and the sexual relationship was reported to have occurred as a result of material need, direct coercion or abuse (Obi, Ozuma and Onyebuchi 2002). Another case study in a hospital setting in Dar-es-Salaam, United Republic of Tanzania, reports that 28 per cent of young women suffering post-abortion complications were made pregnant by men who were about 25 years older than them, evidence that the authors link to a "sugar daddy" relationship (Mpangile, Leshabari and Kihwele 1999). And 73 per cent of 15-19-year-olds admitted to one of the three district hospitals in Dar-es-Salaam for "incomplete" abortion reported that the partner was 30 years or older. In this study girls referred to their partner as "a goat to milk"; sexual services were typically exchanged for small luxuries and several noted that they received no sexual pleasure but "wanted to get it over with as quickly as possible but he is my major source of income." Many used the word "love" to describe their relationships with substantially older partners, but associated this closely with money: for example, "I love him because he gives me money" (Silberschmidt and Rasch 2001). 
In some settings, relations between substantially older women and adolescent boys are also reported in which adolescent males exchange sex for food or pocket money (see for example, Bohmer and Kirumira 1997 for Uganda; Meekers and Calves 1997 for Cameroon). Young males in Uganda appeared to be familiar with this practice, and described how boys can be seduced to have sex against their will or "conned" by older women.

While fewer studies in Asia have reported such relationships, they are evidently not unknown. Studies of firsttime mothers in the Philippines and high-school girls in Korea show that a small minority of the sexually active reported engaging in sex for money (Bautista 1989 for the Philippines; Kim 1998 for Korea). Relations with "sugar mommies" and "aunties" are also reported in a few studies in Asia; however the extent to which these relationships involve any exchange remains unclear (Abraham and Kumar 1999).

The review of 45 sub-Saharan African studies concludes that motivations for engaging in relationships with substantially older partners are varied and overlapping. Common motives include a desire to find love and an economically well-off spouse as well as financial reasons - money, presents and the opportunity to remain in school. This review clubs leading reasons underlying such relationships into three categories: for economic survival, to increase long-term life chances, and to gain status among peers. Evidence suggests that the trend is spiralling and is fuelled by several factors, notably the economic value of sexuality, which is particularly pronounced among adolescents who have fewer economic opportunities than adult women, and because men prefer adolescent girls as sexual partners believing them to be free of HIV (Luke and Kurz 2002).

\section{- $\quad$ Exchange or transactional sex among same-age relationships}

Several studies note that economic transactions also characterise relationships in which both partners are young. These relationships may be more pervasive yet ignored, and are also associated with sexual leverage and a sense of entitlement among young males to force sex on those to whom they have offered gifts (see, for example, Kaufman and Stavrou 2002). In fact, gifts are perceived as a symbol of a girl's worth and a man's interest, and their absence is often taken as humiliation.

For example, in their study of white, Asian and African adolescents in Durban, Kaufman and Stavrou (2002) note that although they were reticent to acknowledge the influence of gifts on their own sexual activities, young people nonetheless agreed that gifts do play a role in negotiating sex and shaping expectations of sexual activity. Studies of out-of-school adolescents in rural Tanzania reiterate this practice and suggest that young men perceive such transfers as a transaction conferring on them the right to force sex on recipient partners while young women perceive gifts and money as a signal of the affection and commitment of the partner (Nnko and Pool 1997; Nnko et al. 2001). Narratives of students in Magu district, Tanzania suggest however that boys do put pressure on girls to respond sexually, but that girls display considerable "competence" in negotiating deals that are financially rewarding. Out-of-school rural adolescents in Magu district, Tanzania suggest gender differences in the interpretation of gifts or money exchanged. While boys perceived a financial motive that girls would not accept a sexual relationship without it, young girls interpreted this exchange as a symbol of commitment, affection and appreciation.

A study in Cameroon also found that virtually all relationships have an economic component, but the importance of this varies from paying for a girl's drinks and food to an explicit exchange of money for sexual favours. In this study young males report that the "main advantage" of having many girlfriends is that "you increase the chance that one of them can help you when you need it" (Meekers and Calves 1997). In a study in Uganda (Bohmer and Kirumira 1997), the practice of exchanging sex for gifts and money is well known among youth: "Girls get tempted so much by money while still young" (female aged 14-16). And: 
I used to see she was being given good things... nice knickers that attracted me too; things like good and expensive creams, soap... which looked expensive... and attractive. Eventually I ended up giving in to those boys. (Married woman aged 17-19; Bohmer and Kirumina 1997 )

Boys in this study noted the financial pressure this practice placed on them — they equated having money with success with girls: "If a girl realises that you don't have money, she abandons you" (male aged 17-19). In this study and the South African study discussed earlier, young people spoke of the "detoothing" of boys, or acceptance of gifts or money by girls but evading the sexual payback. In these cases, even the community considers forcible rape as a justified option:

There are these women who say they are "detoothers," or women who take money and other favours from men and in most cases give nothing in return, but if he gets her in a dark spot he rapes her there, and if the victim knows that she has ever "worked" the man, she does not report the incident. (Girls' group, 17-19 years; Bohmer and Kirumira 1997)

In settings where transactional sex is accepted, lack of sufficient resources to offer girls gifts or money in return for sex can lead young males to resort to rape, as reported by young males in Papua New Guinea (UNAIDS 1999).

\subsection{Sexual coercion in educational settings}

The recent World Report on Violence and Health (WHO 2002) reports that for many, the most common place where sexual coercion and harassment are experienced is in school. This phenomenon may simply reflect the fact that as access to education becomes more widespread, young people spend increasingly longer periods of adolescence in school settings. Schools and colleges are often the locale in which young people interact with peers, and begin to form and negotiate relationships, consensual or not. In addition, however, disturbing evidence suggests that in some cases, the school and college setting gives certain adults the opportunity to abuse positions of authority over young people in the form of sexual coercion.

Sexual coercion within the educational sector takes many forms. A recent review of sexual violence within the educational sector suggests that perpetrators are both teachers and peers; that the forms of coercion may extend from teasing to bullying to harassing victims on their purported sexual experiences to unwanted touch, transactional sex and forced intercourse (Mirsky 2003). In several settings, girls reported that they were verbally humiliated with sexual comments or touched by boys on the breasts or private parts within the school settings. In several studies, young students reported that teachers forced them to engage in sex, and threats and penalties were frequently mentioned as factors forcing acquiescence (Mirsky 2003). Studies have pointed to exchange relationships within the school settings in which teachers demand sex from students in return for grades, or simply use their power to force sex on students. In the Kenyan study discussed earlier, for example, 1-2 per cent of primary school students, and 8 per cent and 4 per cent of secondary school girls and boys respectively experienced pressure from school staff to engage in sex (Ajayi et al. 1997). Indeed, in the South African Demographic and Health Survey, 1.6 per cent of women admitted that they had been raped by the time they were 15 - of these, one-third reported that the perpetrator was the school teacher (Jewkes et al. 2002).

At the same time, many studies have suggested that the context of schooling itself can be dangerous. In several settings, fear of sexual harassment and rape is one reason that parents cite for withdrawing adolescent daughters from school. In both South Asia and sub-Saharan Africa, where girls' school enrolment declines sharply during adolescence, a common reason cited for withdrawing girls from school is the fear of sexual harassment on the way to and from school (Mensch and Lloyd 1998; Sathar and Lloyd 1993). 


\section{Perpetrators of non-consensual experiences}

Studies have rarely explored the characteristics and perspectives of male perpetrators of sexual coercion by interviewing the men themselves. Hence, much of the literature on perpetrators of non-consensual sex among young people focuses on the experiences of young female victims and suggests a range of perpetrators, including peers, known adults and authority figures, those who exchange gifts and money for sexual favours, family members and strangers. Some common themes do, however, emerge: forced sex is rarely perpetrated by strangers and the profile of perpetrators changes, not only by the age of the female victim, but also by the nature of the coercive act. Even so, we recommend caution in interpreting perpetrator profiles, as it may well be hypothesised that adolescents are less likely to report forced encounters perpetrated by persons with whom they are close than others (Erulkar, personal communication).

\subsection{Strangers}

What is clear is that contrary to popular belief, strangers represent no more than a minority of all perpetrators. For example, in Ibadan, Nigeria, only one of 38 young male victims of forced sex and 20 per cent of young female victims reported that the perpetrator was a stranger (Ajuwon et al. 2001a). Similarly among the few Malaysian nursing students reporting rape, strangers constituted less than one-third of all perpetrators (Amar Singh, Wong Woan Yiing and Noor Khatijah Nurani 1996). Among school-going adolescents in Goa, India, strangers were rarely reported as perpetrators of forced penetrative sex, but were frequently reported as perpetrators of unwanted touch by adolescent girls — most commonly mentioned were men who would brush their private parts against girls or touch girls in crowded places such as public buses (Patel and Andrew 2001).

\subsection{Peers and intimate partners}

Many studies concur that among the leading perpetrators of coercive behaviours — particularly among young females - are peers and intimate partners. It is likely, as in the case described below, that age is closely associated with the extent to which peers and intimate partners perpetrate the coercive experience; while younger adolescents may be more likely to be victimised by older men or family members, older adolescents often find that intimate partners (which would include husbands) are most often the perpetrator. Evidence of forced sexual relations in early adolescence (by age 15) comes from Demographic and Health Survey data in South Africa: boyfriends were the reported perpetrators for 10 per cent of all those reporting rape at 15 years or younger, far exceeded by authority figures and even strangers (Jewkes et al. 2002). Among older adolescents the situation is different. In Ibadan, Nigeria for example, among youth aged 15-19, one-third of those reporting forced sex and over 40 per cent of those reporting unwanted touch named a boyfriend as the perpetrator; another 16 per cent and 26 per cent respectively, named a male peer (Ajuwon et al. 2001a). Similarly, a study of primary school girls in the United Republic of Tanzania reveals that 75 per cent reported being sexually "harassed" by school boys, compared to 46 per cent by adult men and 9 per cent by teachers (Mgalla, Schapink and Boerma 1998). In India too, among school-going adolescents in Goa, the most common perpetrators of forced sexual relations reported by both female and male victims were older students or friends (Patel and Andrew 2001). Finally, in a study in Lima, Peru that investigates the experience of young males as perpetrators, a large proportion confirmed that they had coerced their partners into sex (Caceres et al. 1997). 


\subsection{Authority figures}

A major category of perpetrators are figures of authority, ranging from teachers, religious leaders and employers to family members, as well as neighbours and other community members, and adult men more generally.

\section{- $\quad$ Adult authority figures}

Adolescents in several case studies report that coercive events were perpetrated by adult men — including teachers, religious leaders and employers. In the South African Demographic and Health Survey, for example, school teachers were most commonly cited as perpetrators of rape (33 per cent) among girls who reported experiencing rape at 15 years or younger (Jewkes et al. 2002). Religious leaders were implicated in some studies, including those in Nigeria and Zambia (Ajuwon et al. 2001a; Human Rights Watch 2002a). Employers were also mentioned as perpetrators (see Ganatra and Hirve 2002 for India; Kwon Tai-Hwan, Jun Kwang and Cho Sung-nam 1994 for South Korea). In rural Maharashtra, India, for example, 12 out of 16 unmarried adolescent abortion-seekers who agreed to be interviewed in depth reported that pregnancy had resulted from non-consensual sex, and in all these cases, the perpetrator was a known adult male, including an employer (Ganatra and Hirve 2002).

Two studies that shed light on the experience of male victims also conclude that known adult males are frequently perpetrators. A study in Sri Lanka reports that 7 per cent of 314 young men surveyed reported having a coercive sexual relationship with an older man (Silva et al. 1997). And among young men in Ibadan, eight of 38 who reported forced sexual relations and 80 per cent reporting unwanted touch cited a male adult from the community as the perpetrator (Ajuwon et al. 2001a).

\section{- $\quad$ Family members}

Studies also implicate family members, although proportions suffering such abuse appear to vary widely by setting and age of the victim - from under 10 per cent to almost half. For example, in a survey of adolescents and young adults in Trinidad and Tobago, 6 per cent of respondents - all girls — reported the experience of incest (Fraser 2002). Among school-going students in Goa, likewise, parents, relatives and teachers (unfortunately the study does not distinguish between these groups) accounted for a disturbing 12 per cent of perpetrators (Patel and Andrew 2001). The South African Demographic and Health Survey reveals that relatives were responsible for 21 per cent of rapes reported among women by age 15 (Jewkes et al. 2002). Case studies of unmarried adolescent abortion-seekers in rural Maharashtra, India, cited earlier, reveal that of the 12 who reported that pregnancy had resulted from non-consensual sex, four named a family member as the perpetrator (Ganatra and Hirve 2002). A study of nursing students in Malaysia reports that of the 45 perpetrators identified, 19 (or 42 per cent) were family members, the single largest category (Amar Singh, Wong Woan Yiing and Noor Khatijah Nurani 1996). 


\title{
Adverse consequences of forced sex and other forms of sexual coercion
}

\begin{abstract}
A growing body of evidence (see Heise, Ellsberg and Gottemoeller 1999 for a review) indicates that sexual coercion in childhood and adolescence has short- and long-term medical, emotional, psychological and social consequences. Forced sex can lead to health problems such as unwanted pregnancy and sexually transmitted infections (STIs), including HIV/AIDS (Zierler et al. 1991), and sexual dysfunction. Victims of forced sex are more likely than other young people to experience emotional sequelae such as post-traumatic stress disorder, depression and contemplation of suicide (Heise, Moore and Toubia 1995; Luster and Small 1997; Stewart et al. 1996; Stock et al. 1997). Psychological consequences may include feelings of worthlessness and powerlessness; inability to distinguish sexual from affectionate behaviour; difficulty in maintaining appropriate personal boundaries; inability to refuse unwanted sexual advances; difficulty trusting people; shame, fear and guilt about sex; and mental health problems (Stewart et al. 1996). The social consequences of abuse can also be enormous, ranging from poor educational achievement to withdrawal from school, inability to build adult partnerships to loss of marriage prospects, as well as rejection by family or friends who react negatively to disclosure of the abuse/coercion. In addition, research suggests that young victims of sexual abuse are more likely to engage in risky if not self-destructive behaviours, such as unprotected sex, non-use of condoms, early consensual sexual initiation, multiple partners, drug and alcohol abuse, and in severe cases prostitution (Boyer and Fine 1992; Heise, Moore and Toubia 1995; Stewart et al. 1996). Sexual abuse in childhood appears to increase the risk of experiencing further sexual and physical violence later in life. The following section reviews a selection of studies from developing countries that support and illustrate these findings.
\end{abstract}

A qualitative study in Bulawayo, Zimbabwe using semi-structured interviews and group discussions found evidence that a considerable number of unplanned pregnancies resulted from forced intercourse (Hof and Richters 1999). Among adolescents and young adults (up to age 30) in Lima, Peru, females who had experienced sexual coercion were significantly more likely to report sexual health problems (as measured by unintended pregnancy or symptoms of STIs) than others; this relationship was evident but not significant for males (Caceres et al. 1997). The two studies of Ethiopian high-school girls observe several outcomes: in Addis Ababa and Western Shoa, 26 per cent of the 72 girls reporting rape had encountered forced sex on more than one occasion, 24 per cent reported vaginal discharge, 17 per cent reported an unintended pregnancy, and 14 per cent reported an abortion (Mulugeta, Kassaye and Berhane 1998). In the more recent study in Debark Town, of the 19 girls who reported rape, such outcomes as pregnancy, vaginal discharge and abortion were experienced by four, two and one of the victims, respectively (Worku and Addisie 2002).

Other studies have highlighted that the link between coercion with early pregnancy and HIV/AIDS may be both direct and indirect, and short- and long-term, because the experience of coercion appears to increase the risk of subsequent early and unprotected sexual behaviour (see for example Boyer and Fine 1992). In Barbados, sexual abuse in childhood or adolescence constituted the primary determinant of years of sexual activity in adolescence (by age 20) for both females and males (Handwerker 1993). Indeed, among males, sexual abuse in adolescence was strongly associated with non-use of condoms in adulthood. Similarly, a study in the Central African Republic found that among both women and men aged 15-50, the risk of having multiple partners at the time of the study was significantly higher among those reporting forced sexual initiation than those for whom it was consensual (Somse, Chapko and Hawkins 1993). Compared to those whose first sex was 
consensual, men and women whose initiation was forced were 2.47 and 1.77 times more likely to report multiple partners in adulthood.

A few studies from developing countries have also explored the psychological consequences of sexual coercion and abuse. For example, among abused children and adolescents in Karachi, Pakistan, three-quarters reported feelings of guilt, rejection, anxiety and sadness, and almost all reported feeling suicidal at some point in their lives (United Nations ESCAP, Government of Japan, National Commission for Child Welfare and Development, Pakistan 2001). Studies among school girls in Ethiopia also report significant mental health consequences among raped girls. In Addis Ababa and Western Shoa, 35 per cent and 31 per cent reported self-blame and anxiety respectively, and 6 per cent reported attempted suicide (Mulugeta, Kassaye and Berhane 1998). In Debark Town, of the 19 girls who reported rape, three reported attempting suicide, and several more reported feelings of anguish and hopelessness (Worku and Addisie 2002).

Studies also report adverse consequences with regard to school continuation and performance (see for example Mulugeta, Kassaye and Berhane 1998; Patel and Andrew 2001; Worku and Addisie 2002). In the Ethiopian studies for example, 14 per cent of rape victims in Addis Ababa and Shoa, and 21 per cent of those in Debark Town reported failing in school. In Kenya, girls' progress in the classroom was often undermined by teachers' attitudes and by teasing on the part of male classmates; dropout rates for girls were higher in schools where teachers' attitudes favoured boys (Mensch and Lloyd 1998).

In cases when forced sex results in premarital pregnancy, many girls experience severe social consequences, including withdrawal from school, rejection by family members, forced abortion and reduced marriage prospects. Research from South Africa (Wood and Jewkes 2001; Wood, Maforah and Jewkes 1998) suggests that where coercion results in unwanted pregnancy, girls are likely to discontinue their education. As noted earlier, fears of sexual harassment and coercion in school, and on the way to and from school, inhibit many parents in settings as diverse as sub-Saharan Africa and South Asia from keeping their adolescent daughters in school. Moreover, in extreme cases, particularly in traditional societies of South Asia and the Middle East, disclosure may put young women at risk of being killed by their own families in so-called "honour killings" (see, for example, Human Rights Watch 1999; Shalhoub-Kevorkian 2000).

Evidence also suggests that adolescents who have experienced an incident of sexual coercion are at risk of experiencing further sexual and physical violence. For example, young people attending programmes for adolescents in Peru (INPPARES) and Colombia (PROFAMILIA) who reported an experience of unwanted sex stated that the incident had occurred more than once (Stewart et al. 1996). Similarly, a study of school-going adolescents in Goa, India, indicates that sexually abused adolescents are more likely than their peers to have experienced other forms of violence and abuse in the previous 12 months. Of the 266 adolescents who had been abused, nearly half (47 per cent) reported more than one experience of abuse and nearly a quarter (24 per cent) reported three or more such experiences (Patel and Andrew 2001). 


\section{What are the underlying risk factors?}

The World Report on Violence and Health cautions that sexual violence is complicated by the multiple forms it takes and the contexts in which it occurs, and by the fact that risk factors may vary in importance according to the life stage of the victim (WHO 2002). The report cites a number of factors that may increase the vulnerability of women in particular to sexual violence, namely young age, alcohol and drug consumption, previous experiences of abuse, multiple partner relations and poverty.

Some research has explored the types of structural and environmental factors that put young people at greater risk of sexual coercion, including poverty, patriarchy, societal norms that support sexual violence and gender inequity, early marriage, inadequate educational and health systems, and ineffective laws and policies. Most available studies have focused on young women's — rather than young men's — experiences and suggest that young people who experience non-consensual sexual experiences are more likely than others to report poor educational attainment, migrant status, residence away from parents, and alcohol and drug use (see for example, Bohmer and Kirumira 1997; Cheng Yimin et al. 2001; WHO 2002), although, in some cases these may be consequences of rather than risk factors for abuse. Anecdotal evidence points, moreover, to such factors as crowded housing conditions and the lack of adequate or safe housing as additional, yet unexplored, factors.

While few studies have directly explored beyond these factors, the context of non-consensual relations described in these largely qualitative studies offers an insight on the kind of risk factors that make for a dangerous environment for young people. Aside from the structural factors noted earlier, these factors work at the individual, family, community and systemic levels. Prominent among these are gender double standards, power imbalances and inadequate negotiation skills, lack of awareness of rights and opportunities for recourse, lack of supportive environments and trusted adults on sexual health matters, unfriendly institutional responses (health, crime, legal), and perhaps most important, a failure on the part of social and legal institutions in the community to recognise the problem and punish the perpetrators rather than the victims. We highlight below what is known in each of these areas.

\subsection{Gender double standards and lack of awareness of rights}

Gender double standards appear to be a consistent factor underlying non-consensual sexual experiences of young people in every setting in which the link has been studied. However, researchers report that violence against women in general - including both physical and sexual violence - appears to be more common in settings where gender roles are rigidly enforced and where there is a stronger association between masculinity and dominance (see for example, Heise, Ellsberg and Gottemoeller 1999). Several studies illustrate the ways in which norms associating masculinity with toughness and dominance, and femininity with submissiveness, pervade the sexual lives of young people. A comparative analysis of qualitative studies of the contextual factors affecting sexual risk among young people in several countries (Cambodia, Cameroon, Chile, Costa Rica, Papua New Guinea, Philippines and Zimbabwe) reveals that sex-specific norms of behaviour are evident in all settings and contribute to the widespread experience of coerced sexual activity among young women (UNAIDS 1999). Double standards that condone premarital and extramarital sexual relations for men but stigmatise sexually active women often make it difficult for young women to communicate about, seek help for, or escape from coercive or non-consensual sexual advances. This analysis and other studies have found that young 
people in many different settings report a widely held (mis-)perception that young women who resist sexual advances are conforming to traditional role expectations and in fact enjoy the coercive incident (see for example, Ajuwon et al. 2001b for Nigeria; Anonymous 2000 for South Africa). Double standards extend to the justification of intimate partner violence by young females and males: for example, in a recent study in Ghana, 56 per cent of boys and 60 per cent of girls argued that it was acceptable for a boy to beat his girlfriend in some circumstances (Glover et al. 2003). Equally disturbing is the perception among young victims that rape was "inevitable" in their setting because males were uncontrollable, and because rape was an acceptable or "normal" way to "teach a haughty girl a lesson" (Ajuwon et al. 2001b).

Double standards surrounding motives for engaging in consensual sexual relations also increase young females' vulnerability to forced sexual relations. In many countries significant proportions of young females report that they engage in sex as a show of commitment, while young males are more likely to report such motives as curiosity, peer pressure or sexual desire (Brown et al. 2001). These differing motives can have major repercussions for forcing or pressuring sex. A study of young people in Mexico reports for example that "men also report telling women that they love them in order to persuade them to accept sexual intercourse, using their knowledge of the social disapproval of women who have coitus outside loving relationships. Men report that their friends sometimes allow women to think that they are novias [fiancées] in order to gain sexual access to these women" (Marston 2003). The narratives of girls likewise also suggest that they acquiesce to sex in the belief that this would lead to marriage.

\section{- $\quad$ Among young men}

Unequal gender norms have perpetuated a sense of entitlement to sex among young men and a widespread perception reported in many regions that men's sexual needs are beyond their control and demand immediate satisfaction (see Ajuwon et al. 2001b for Ibadan, Nigeria; Balmer et al. 1997 for Kenya; Sodhi and Verma 2003 for New Delhi, India; Varga 1997; Wood and Jewkes 1997 for South Africa). For example, in a study of over 27,000 young women and men in South Africa, in which one-quarter of young men reported having committed rape by the age of 18, one in 10 young men considered gang rape to be "cool" (Anonymous 2000). Likewise, young South African men in Varga's (1997) study argue: "There are no negotiations on that issue. If my penis wants it, it must get sex," and "If she refuses, you must just force her."

Narratives from other settings reinforce this notion:

I would say that it's the penis which influences a person to rape. When the penis is in the mood...eventually he will rape her. (Focus group discussion, boys aged 14-16, Uganda; Bohmer and Kirumira 1997)

This sense of entitlement is particularly strong when young males perceive a threat to their masculinity. For example, a study in Kenya reports that young men distinguish justifiable from unjustifiable coercion: "brutal" rape is the assault of a female by a stranger or gang and is unjustifiable (Balmer et al. 1997). In contrast, "soft" or justifiable rape occurs among girls and young women who are perceived to deserve it for flaunting themselves, leading partners on or giving mixed messages. A comparative analysis of qualitative studies of the contextual factors affecting sexual risk among young people in Cambodia, Cameroon, Chile, Costa Rica, Papua New Guinea, Philippines and Zimbabwe notes, however, that despite premarital sexual activity being condoned among young men, they are left to pursue it in "almost total silence and the absence of support"; this failure to engage young men in the discourse on sexuality may be a factor underlying the use of force in sexual relationships (UNAIDS 1999).

\section{- $\quad$ Among young females}

In many settings, these norms are translated into fear, expectation or even acceptance among communities including young women - that men will try to pressure women by force. At the same time, where coercion is experienced, there is a tendency in most societies to hold the victim (woman) responsible. There is a perception - 
among boys and young men but also girls and young women — that female victims "invited" the coercive incident and that women who are victims of forced sex are in some way responsible. In a study in Uganda, for example, respondents maintained that victims invited the coercive incident through inappropriate dress or speech (Bohmer and Kirumira 1997). Another study in Mbale district, Uganda, drawing from focus group discussions among 17-18year-old adolescents, reiterates that adolescents tended to blame themselves when rape occurred because "they were not allowing a man to have sex, which is natural" (Hulton, Cullen and Khalokho 2000).

Many studies highlight that young women and girls, married and unmarried, believe that succumbing to sex by pressure or force is a necessary component of marriage or a steady relationship. Among 11-15-year-old schoolgoing adolescents in Jamaica, 69 per cent of boys and 32 per cent of girls agreed that "if you really love your [partner], you should have sex with them" and more than half ( 58 per cent) of boys and 30 per cent of girls said that if a boy "spends a lot of money on a girl" she should have sex with him (Eggleston, Jackson and Hardee 1999).

In several studies, girls reported continuing to comply with male sexual demands for fear that if sex was refused, the partner would lose interest (see Sodhi and Verma 2003 for India; Wood, Maforah and Jewkes 1996 for South Africa). In a study of low-income urban adolescents in Delhi, India for example, several girls described the evolution from dating to sexual relationships as forced. The case of a 15-year-old girl is illustrative. She describes being deceived into providing an opportunity for forced sexual initiation, experiencing not only forced sexual relations but also physical violence, and being unable to withdraw from the relationship:

[He] kissed me forcefully.... He took me there on the pretext that he had to talk to me....[H]e gets angry if I talk to anyone in the lane. One day he saw me talking to my brother...he came in the evening and beat me up. He said the boy was my yaar [friend]...he beat me so much even then I did not say anything to him because I love him so much. (Sodhi and Verma 2003)

This sense of entitlement is even stronger in relationships in which gifts are involved. Luke and Kurz (2002) report that sexual violence can be a relatively frequent response to young females who overstep the bounds of their bargaining power. Indeed, in some settings, rape is considered a justifiable outcome if an adolescent accepts gifts and then refuses to engage in sex, which is described as "detoothing" the male or having "eaten the money but failed to pay back through sex."

The sense of entitlement is strongest in marital relationships. Several studies report young women's helpless acquiescence of marital rape. For example:

...the girl knows that on the first night the boy will have sex with her. Even if the girl refuses, he will do sex forcefully. (18-year-old girl, New Delhi, India; Sodhi and Verma 2003)

Closely tied with these double standards is a lack of awareness among adolescents about their rights. In a study in Johannesburg and neighbouring areas, more than half of young women considered that raped women were at least partially responsible for the rape, and over 10 per cent argued that they had no right to avoid sexual abuse; 30 per cent of young men thought that women who were raped "asked for it" (Anonymous 2000). In another study, adolescents argued: "as a woman you have no rights. You must keep quiet and do as the man wants” (Wood, Maforah and Jewkes 1996).

Married adolescents in many settings similarly perceive that acquiescing to forced sex by husbands is part of their marital duly. A married adult woman from rural Uttar Pradesh, India recounted her early sexual experiences thus:

Once when I gathered the courage and told him I wanted to avoid sex with him, he said what else have I married you for?... Then I thought, after all, wasn't I born for this purpose? It is my duty to serve my husband and that is all that I should remember. (Khan et al. 1996) 


\subsection{Inadequate communication and the inability to negotiate on sexual matters}

Lack of communication between partners on sexual matters and the skills to negotiate a wanted outcome are obvious risk factors (see, for example, Wood and Jewkes 2001; Wood, Maforah and Jewkes 1998). In many ways, direct communication is replaced — and conflict resolved — by actions, notable among which, in the area of sexual relations, are force and coercion. For example, in Kenya, boys cited the inability to communicate with or approach girls as a reason for committing rape and even gang rape (Balmer et al. 1997). In Uganda, gifts and money rather than communication between partners, define the process of sexual negotiation (Bohmer and Kirumira 1997). Studies in South Africa conclude that adolescent girls accept force as an expression of love from the partner (Wood and Jewkes 1997). In several settings, adolescent boys perceive forced sex as a way of “punishing” a girl (Ajuwon et al. 2001b for Nigeria; Wood and Jewkes 1997 for South Africa).

Young females are acutely aware of their inability to negotiate with partners about sex, and acknowledge the link between their powerlessness in sexual negotiation and other matters and their acquiescence to forced sex. In a qualitative study of 25 young women aged 14-24 in Bulawayo, Zimbabwe who became mothers in adolescence, several acknowledged this link and their inability to refuse sex:

A woman can refuse but then this woman will run the risk that she will be forced into sex. I would like to change it, but it cannot be done because a woman needs to follow the man. (16-year-old)

If my boyfriend would refuse me using contraceptives, then I would want to refuse having sex with him. However, if I refuse sex, I will be accused of wanting other boys and he will leave me. Ifeel powerless because I know I will be in a no-win situation. (16-year-old; Hof and Richters 1999)

Even when negotiation is attempted, many adolescent girls report that they are unable to prevent a forced sexual encounter. A study of adolescents in South Africa reports that although girls were well aware of power differentials, inequities and double standards operating in sexual relations, they recognised their inability to refuse sex (Varga 1997). In this study, although over half of female respondents reported refusing sexual advances from their most recent partner, as many as 71 per cent reported that attempts to refuse sex were ultimately unsuccessful.

Again, when gifts and money are exchanged, young women are particularly powerless to negotiate a wanted outcome. A review of studies in sub-Saharan Africa notes that once gifts are accepted (and depending on the value of the gift), girls perceived that they had no right to even insist on condom use; hence transactional sex significantly reduces young women's bargaining power for safer sex (Luke and Kurz 2002).

Likewise, in settings where premarital sexual activity for girls is particularly sanctioned, sexually active young women report their inability to negotiate out of an unwanted relationship. They report that the threat of revelation of a relationship may lead to severe repercussions with regard to their own reputation and future but would have no adverse consequences for young men. Studies suggest that given this double standard, boys use threats of disclosure to demand sex and to continue to impose unwanted sexual relations on unwilling girls. Girls report pressure to acquiesce, as narrated by a young man in a Delhi slum:

[I]... gave her dhamki [threat] that if she does not do [have intercourse] then I will tell everybody. Then I started taking money for each sexual intercourse. I used to threaten her that I will tell everybody. She used to give me Rs. 20, sometimes Rs. 50, 100. (Sodhi and Verma 2003) 
Studies also suggest that the location of the forced incident can further limit a young woman's ability to negotiate. In a study of 24 Xhosa girls aged 14-18 seeking antenatal care in South Africa, many revealed that they had been "deceived" into sex. Girls reported agreeing to accompany the man home in order to talk, drink or do his ironing and being unable to negotiate themselves out of having sex thereafter, as they faced threats and assault if they resisted (Wood, Maforah and Jewkes 1996). In-depth interviews with 61 sexually experienced young women aged 16-22 in Mexico City suggest two factors that particularly limit negotiation among young women - physical location and previous sexual experience (Marston 2003). Several respondents reported that if a woman was alone with a man in his home or elsewhere, she would be unable to negotiate her way out of forced sex:

...he just penetrated me ....I got up and left but...because...going alone to his flat, well from the start that's sort of instigating it. (Female, aged 21; Marston 2003)

Interestingly, young women who were not virgins considered that this fact could limit their right to refuse sex. Some women said that once they had engaged in sex with a boyfriend, they were expected to continue to do so, and felt pressured into doing so. Others reported that it was difficult to refuse sex with a new partner if he knew that she was not a virgin:

"I explained to him.... You have to have a relationship, know them more in depth .... So he asked me: are you a virgin? And I told him: ... no I'm not, but just because I'm not doesn't mean that I'm going to sleep with just anybody. And I explained to him, and he just kept on.

(Female, aged 22; Marston 2003)

Other factors that can limit a young woman's ability to refuse unwanted sex from a romantic partner are verbal pressure, or the threat of breaking a relationship or seeking other partners. Both young women and men in several case studies from developing countries appear to recognise the role of verbal pressure in weakening a young woman's ability to negotiate refusal of sex (Brown et al. 2001).

\subsection{Lack of supportive family and peer environments on sexual health matters}

Young people, especially girls and young women, perceive that their parents, families and communities are, by and large, neither supportive nor non-judgemental with regard to their sexual experiences — whether consensual or non-consensual. These perceptions can clearly deprive young people of the supportive environment necessary to navigate healthy and wanted sexual outcomes. Evidence indicates that sexual violence and harassment are common events even in settings in which parents strictly limit girls' interaction with the opposite sex (see, for example, Mehra, Savithri and Coutinho 2002a; 2002b for India). In fact, anecdotal evidence suggests that the taboo against intermingling of the sexes and the resulting perceptions of an unsupportive environment may actually compound risk factors. For example, boys and men in these settings have been observed to use the threat of ruining a girl's reputation as a way to pressure a girl to have sex or keep quiet about an incident of abuse or harassment (see Sodhi and Verma 2003 for India). In most settings, but particularly those in which gender double standards are widely prevalent, while parents strictly limit the autonomy and mobility of their daughters, they often tolerate and excuse abusive or promiscuous behaviour of boys and young men, reinforcing in them a sense of entitlement to sex, and a recognition that they will suffer few consequences for harassment or abuse of young women. At the same time, the taboo against discussing sexual issues between adolescents and parents makes it unlikely that a girl will turn to her parents for help if she feels threatened or needs help in resolving ongoing harassment or abuse. Several studies report, for example, that young girls refrain from discussing sexual matters and issues of coercion with their parents because they perceive that their parents will be unsupportive or will accuse them of having incited the coercive incident. For example, adolescents in 
FIGURE 4: Role of perceived parental support in protecting adolescents from forced sex, Goa, India

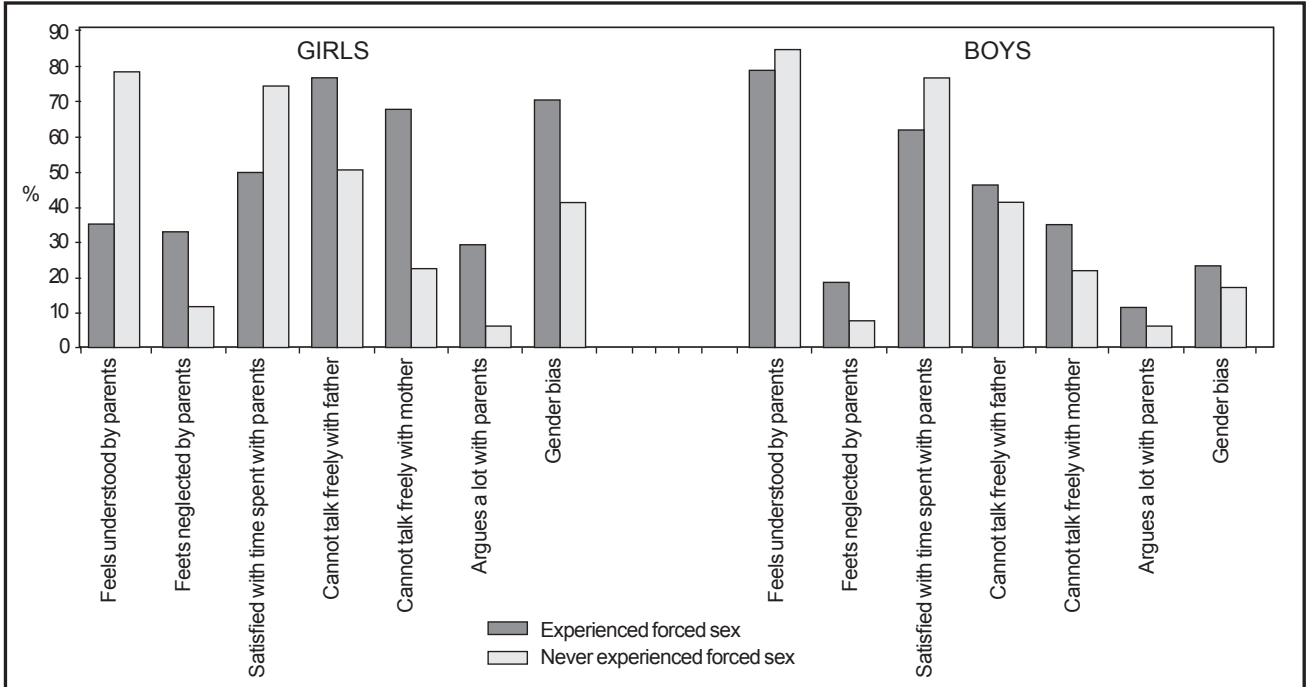

Source: Patel and Andrew 2001.

Uganda feared that telling the family about rape would lead to misunderstanding or being sent away from home (Bohmer and Kirumira 1997).

A study in Kenya finds for example that young girls perceive that the extent of support they will receive varies according to the nature of the coercive incident and the relationship with the perpetrator. They acknowledge that unless the perpetrator is a stranger, it would not be prudent for them to seek help from parents or the police. They report that in the case of rape perpetrated by a known person, they would be inhibited from complaining for fear that their parents would accuse them of colluding with the perpetrator or parade them around in the community complaining they were raped, or that the police would accuse them of prostitution (Balmer et al. 1997).

Few studies have explored the protective influence of close relations with parents. While cause and effect remain unclear, the study of school-going adolescents in Goa, India, finds a consistent positive relationship between closeness to parents and freedom from forced sexual relations (see Figure 4). For females in particular, findings suggest that adolescents who report a close relationship with parents were significantly less likely to have experienced forced sex than other adolescents.

A similar link can be inferred from a study that explored the socio-demographic characteristics of victims of non-consensual sexual relations in Beijing, China (Cheng Yimin et al. 2001). In this case-controlled study of 1,393 unmarried abortion-seekers aged 22 or younger, women who reported a non-consensual sexual experience were more likely than others to report the absence of familial support: they were significantly (odds ratio of 1.63) more likely to be unregistered migrants (floating population) and less likely to co-reside with parents $(\mathrm{OR}=1.57)$ than those who did not report non-consensual sexual experiences. The Human Rights Watch (2002a) study in Zambia also suggests that parental presence itself is a supportive factor: in this study, girls who had lost their parents were particularly vulnerable to rape by family members who gave them shelter. 


\section{Response to and by the victim}

Evidence suggests that the same factors that create a risky environment for young people also inhibit young victims from seeking help.

\subsection{Responses of young persons who experience coercion}

Studies highlight that the typical response of a victim to sexual coercion is inaction. In the study in Goa, India, for example, only 15 per cent of female victims and not a single male victim shared the experience with friends or parents (Patel and Andrew 2001). Likewise, a study in Karachi, Pakistan (United Nations ESCAP, Government of Japan, National Commission for Child Welfare and Development, Pakistan 2001) reports the inaction of young female and male victims. A study of adolescents seeking counselling in clinics in Colombia and Peru similarly reports that as many as two-thirds had never told anyone about the coercive experience (Stewart et al. 1996).

Given the pervasiveness of attitudes that blame the victim, it is not surprising that many young people who experience sexual coercion do not turn to their friends or family for help because they believe that they will not receive support. Studies, for example in Kenya and Nigeria, revealed that adolescent girls and boys who experience coercion were afraid to draw attention to themselves for fear of being blamed by the family and society for the incident (Ajuwon et al. 2001b; Balmer et al. 1997). A study of adolescents seeking counselling in clinics in Colombia and Peru reports that leading reasons for not seeking help were related to shame, fear and threats from the perpetrator (Stewart et al. 1996).

\subsection{Response of family members, friends and community members}

There is considerable evidence that young peoples' fears of a negative response from the family, friends and the larger community are not unfounded. For example, the Human Rights Watch (2002a) study in Zambia reports that abuses - perpetrated by family members, boyfriends and figures of authority — are often hidden by families, and girls who report an incident are advised to keep silent and not bring shame upon the family. In some cases, they are threatened with physical abuse if they reveal the coercive incident. Shame and stigma are pervasive and families often blame the girl herself for inciting the incident. Likewise, a study in Karachi, Pakistan (United Nations ESCAP, Government of Japan, National Commission for Child Welfare and Development, Pakistan 2001) reports how lack of family support compounds the trauma for young victims. A female victim reports:

When I told my mother about the ugly incident [rape by an uncle], she didn't believe me. She beat me black and blue. She could never think that her real brother could do it to me. She ordered me to keep my mouth shut.

In extreme cases, rape victims may be murdered by family members, who believe that family honour can only be restored by the death of the woman (Graitcer and Youssef 1993; Palestinian Human Rights Monitor 2002). 
Peers are not necessarily any more supportive of young victims than are parents. Young women are unlikely to confide in peers about a coercive incident, and if they do, are unlikely to be counselled to take action (see Ajuwon et al. 2001a). A study of Xhosa adolescent girls in South Africa reports that even peers advocate silence as the most appropriate response to forced sex. For example, one woman reports a peer's reaction:

...made me stop crying and promise that I wouldn't tell my mother or anyone else, that I should go home, clean myself up and keep quiet about what happened. (Wood, Maforah and Jewkes 1996)

Indeed, as seen earlier, peer support can be influential among young males in encouraging the perpetration of forced sexual relations.

\subsection{Response of the health sector and law enforcement agencies}

Ideally, young people who experience sexual coercion/violence should be able to turn to health care providers, social service agencies and law enforcement agencies for help that their friends and family cannot provide. They need compassionate sources of counselling, emergency contraception, STI treatment and care for other kinds of health problems. In cases of rape, victims need the services of someone recognised by the courts as qualified to document evidence with legal validity (in many countries a medical doctor is not considered qualified to document legal evidence of rape by the law). In cases where a young woman or man would like to bring charges against a perpetrator, victims need a competent and sensitised police force and judicial system. Above all, these services need to be delivered in compassionate and non-judgmental ways. Unfortunately, throughout the developing world (and many parts of the developed world), an appropriate institutional response is lacking (if not non-existent). In many cases, the experience of seeking help from health care providers, much less the police, is traumatising and the same negative attitudes towards victims of violence that permeate the larger society are rampant among the staff of health care institutions, and even more so among the police and judicial systems (Heise, Ellsberg and Gottemoeller 1999; Human Rights Watch 1999). Young people themselves appear to be aware of the lack of institutional support. In Uganda and Ethiopia, for example, young people are reported to be well aware that the majority of rapes are not prosecuted and that more stringent punishment is needed (Bohmer and Kirumira 1997; Worku and Addisie 2002).

Indeed, the response of the health sector, judiciary and law enforcement agencies can exacerbate rather than ameliorate the negative impact of a coercive experience (for example, see Heise, Ellsberg and Gottemoeller 1999 and relevant issues of Human Rights Watch reports such as Human Rights Watch 1999). While few studies have explicitly explored this issue, studies from India and Nigeria highlight the fact that the police and prosecutors often fail to address victims in a sensitive and professional manner, and few reported rape cases result in convictions (Gangrade, Sooryamoorthy and Renjini 1995; Omorodion and Olusanya 1998). 


\section{Summary and key recommendations}

The objective of this paper was to review what is known about non-consensual sexual relations and sexual coercion among young people in developing countries. What is clear is that studies of non-consensual sexual relations and sexual initiation among young people are sparse. The profile depicted here has relied on a small, pioneering case studies in selected settings drawn from selected sub-populations of youth; consequently, findings may not be representative. Also clear is that existing studies adopt varying and somewhat ambiguous definitions of non-consensual sexual experiences; and that, as this is one of the most methodologically difficult and sensitive areas of sexual health to research, responses to questions in standard survey instruments may not be entirely reliable.

Notwithstanding these very real limitations, the few available studies provide many common insights and have suggested that although definitions, study populations and study designs may differ, making comparison difficult, non-consensual sex is indeed experienced by disturbing proportions of young people in all settings from which data were drawn. Coercive sex is experienced largely by girls and women, but also by boys and men, as well as those in same sex relationships (although the literature on this is sparse). While sexual coercion has been studied largely among the unmarried, there is evidence that it is common among married couples as well. Such incidents occur largely among individuals who are acquainted with each other. Sexual coercion covers a continuum of behaviours ranging from unwanted verbal advances to unwanted touch to assault and forced sex, as well as sex in exchange for money, gifts, food or protection. The consequences of sexual coercion are formidable: they are short- and long-term, and physical, psychological and social. Sexual health manifestations range from unintended pregnancy, abortion and infection to risk-taking behaviours, including early onset of consensual sex, multiple partner relations and non-use of condoms. Psychological outcomes range from symptoms of anxiety and depression to suicide attempts. School performance can also be affected.

A number of obstacles inhibit adolescents from protecting themselves from non-consensual sexual relations and from taking action against a perpetrator or to withdraw from a coercive relationship. Gender double standards and expectations of women and men in the sexual arena dominate these obstacles. Communication and negotiation on sexual matters, moreover, tend to be difficult and are often replaced by actions that include force and violence to resolve differences. The lack of a supportive environment and trusted adults and peers to consult on sexual health matters may also enhance young people's (and particularly young women's) vulnerability to coercive sexual relations. Perceptions of institutional indifference - at the community, school, legal and health sector levels — can inhibit help-seeking both among victims as well as others who may wish to seek counselling on how to confront a potentially threatening situation.

\subsection{Programme recommendations}

Sexual and reproductive health programmes for young people are largely premised on consensual sex: they often aim to increase young people's knowledge of safe sex, advocate abstinence or condom use, and provide sexual health services in youth-friendly ways. They are not necessarily equipped to deal with the needs of young people who experience non-consensual sex, whose needs go far beyond receiving more information on safe sex. At the same time, programmes that deal explicitly with non-consensual sex are often narrowly defined. Their focus has tended towards improving the management of the few rape cases that are actually 
reported to the police, on the assumption that increasing the chances of apprehending and sentencing perpetrators will act as a deterrent. While this is a necessary step, it is not sufficient.

There is a paucity of published literature on programmes that address non-consensual sex among young people, and the absence of a discussion of these in this review is a reflection of this sparse information. We acknowledge that this limitation makes it difficult to draw programme recommendations from this review. However, the evidence presented in this review underscores a number of factors that appear to compound young people's vulnerability to sexual coercion, and a perusal of these suggest a number of programmatic actions:

- Education, counselling and service activities that address non-consensual sex among young people must be integrated into existing programmes and extended to reach places where young people congregate

Non-consensual sexual experiences have major implications for STIs and HIV, for young people's health and development, and for their rights. Yet, neither school activities, nor STI/AIDS prevention programmes nor reproductive health and family planning services typically address these concerns. Steps must be taken to fold appropriate prevention and care activities into existing programmes and facilities, and to reach young people outside of schools and health facilities - at youth centres, in programmes for the out-of-school and wherever else they may gather.

- Sexuality education activities must counter traditional gender stereotypes and equip young people with the awareness and skills necessary to protect themselves from coercive encounters and to seek appropriate care in case of such incidents

Evidence suggests that young people may accept sexual coercion as inevitable in their lives and may not perceive options in practice that enable them to prevent or seek help for such incidents. Sexuality education must dispel these misperceptions, reverse ingrained norms of gender double standards, power imbalances and male entitlement to sex, and reinforce life and negotiation skills activities that strengthen young people's ability to protect themselves from unwanted sexual advances and to take appropriate action should such incidents occur.

- Sensitise parents, teachers and other trusted adults with whom young people interact to the importance of communicating about sexual matters with youth and of providing a supportive and non-judgemental environment more generally

The importance of a supportive environment — and in particular a close relationship with parents — has been stressed in available studies as a protective influence. Findings have also suggested that known adult males are frequently perpetrators of sexual coercion among young people and that fears of censure from trusted adults inhibit young victims from disclosing a coercive experience. Programmes are needed therefore that apprise adults, particularly parents, of the reality of sexual coercion and the need to communicate with their children on sexual matters, and to provide their children a supportive environment where they can raise sexual health concerns.

- $\quad$ Train providers to identify adolescent victims, to understand the links between sexual violence and health and rights, and to provide them sensitive counselling, appropriate services and safe options

Case studies suggest that many health providers have negative attitudes towards those who experience sexual coercion/violence (for example, see Guedes et al. 2002). These findings suggest the need to train health providers to recognise and enquire sensitively about sexual abuse. Ideally, health providers should be able to 
provide appropriate counselling and services that enable young victims to deal with the incident, and assist others who may not have experienced the "tip of the iceberg" in protecting themselves from further and even more severe forms of coercion. They also need to know how to provide emergency contraception and basic referrals to available competent and compassionate community services (including the police) to help young people who have experienced sexual violence.

\subsection{Research recommendations}

A number of gaps in understanding sexual coercion among young people persist. Aside from the substantive gaps outlined below, study designs and methodologies need to be refined to ensure they are appropriate for youth. The ethical imperative of protecting confidentiality and providing sensitive counselling and referral to those in need must be established.

\section{- Arrive at uniform definitions and appropriate measures that unambiguously recognise the multiple dimensions of non-consensual sexual experiences that young people face}

This review has highlighted that both researchers and young people themselves define non-consensual sexual experiences in different ways. Non-consensual sexual experiences are multi-faceted: each facet needs to be systematically addressed and the boundaries more clearly delineated. Yet for many, non-sexual experiences remain narrowly defined and equated with violent rape. Ambiguity persists on the ways in which other behaviours - for example, forced sexual relations following threats and intimidation, partner pressure, promises of gifts, money or other transactions on the one hand, and non-penetrative experiences such as unwanted touch on the other - are defined. These dimensions of non-sexual experiences need to be included with enough clarity so as to enable the development of appropriate programmatic and policy responses.

\section{- Investigate the prevalence and context of non-consensual sexual relations and initiation among young women and men, unmarried and married}

Case studies have uniformly highlighted the existence of coercive sexual behaviours among young people, both as victims as well as perpetrators. Yet the majority of these studies have obtained information on forced activity as part of more extensive research of sexual behaviour and few have focused exclusively on coercive experiences. Studies are needed that explore the extent of coercive behaviours in different cultural settings and sub-populations - females and males, younger and older groups, married and unmarried youth; at the same time, there is a need to explore the context in which coercive relations occur - typical partners, typical sequence of events, motives expressed for the coercive act, perceptions among youth of what constitutes coercive behaviour and attitudes justifying such acts.

Research must also shed light on findings of case studies suggesting that adolescent and young men — albeit comparatively fewer - are also exposed to non-consensual sexual experiences - both as victims and perpetrators. What are the kinds of coercion that young male victims experience? Who are the perpetrators? What do young men mean when they suggest that coercion was perpetrated by girlfriends? How do young male perpetrators describe and understand different kinds of coercive incidents?

\section{- Explore factors that place young people at heightened risk of, and protect them from coercive sexual advances and relations}

This review suggests that gender double standards and power imbalances, limited communication and negotiation skills and lack of a supportive adult environment play a powerful role in exposing young people, especially adolescent and young women, to coercive sexual relations. Studies are needed that explore these and other 
potential risk factors, and reveal the extent to which a supportive environment, life skills and self-esteem, and gender egalitarian attitudes protect young people from coercive relations. In particular, it would be useful for studies to document the experiences of communities in which social norms and attitudes about sexual coercion have changed for the better.

\section{- Study the perspectives of young women and men who have experienced sexual coercion to identify what services and assistance they feel would have been helpful}

The available evidence suggests that by and large, young people who have non-consensual sexual experiences - whether verbal intimidation, unwanted touch or rape - perceive few help-seeking options in practice. Most stay silent and do not seek help, whether from family, friends, health care providers or the police. Research is needed that explores young people's awareness of available service options, whom young victims turn to for counsel, whether a sequence of help-seeking options is pursued, the quality of available counselling or services, and the extent to which they rate their help-seeking experiences positively.

Thus far, the issue of sexual coercion among young people has remained largely outside the scope of sexual and reproductive health promotion activities in developing countries. Findings from this review suggest however that coercive sexual experiences may be a key factor underlying the compromised sexual and reproductive health of adolescents and youth in many developing countries, and specifically the spread of HIV in this population. Focused research that highlights the magnitude and context of coercive experiences is essential in shaping evidence-based interventions that break the silence around sexual coercion of young people and reduce young people's risk of sexual violence. 


\section{References}

Abraham, Leena and K.A. Kumar. 1999. "Sexual experiences and their correlates among college students in Mumbai City, India," International Family Planning Perspectives 25(3): 139-146, 152.

Ajayi, Ayorinde, Wesley Clark, Annabel Erulkar, Karin Hyde et al. 1997. Schooling and the Experience of Adolescents in Kenya. Nairobi: The Population Council.

Ajuwon, A.J., Benjamin Oladapo Olley, Iwalola Akin-Jimoh and Olagoke Akintola. 2001a. "Experience of sexual coercion among adolescents in Ibadan, Nigeria," African Journal of Reproductive Health 5(3): 120-131.

Ajuwon, A.J., I. Akin-Jimoh, B.O. Olley and O. Akintola. 2001b. "Sexual coercion: Learning from the perspectives of adolescents in Ibadan, Nigeria," Reproductive Health Matters 9(17): 128-136.

Alarcon, I. and G.F. Gonzales. 1996. "Attitudes towards sexuality, sexual knowledge and behaviour in adolescents in the cities of Lima, Cusco and Iquitos," Lima, Peru, Cayetano Heredia Peruvian University, Unpublished final report submitted to the UNDP/UNFPA/WHO/World Bank Special Programme of Research, Development and Research Training in Human Reproduction, Geneva.

Amar Singh, H.S.S., Wong Woan Yiing and H.J.H. Noor Khatijah Nurani. 1996. "Prevalence of childhood sexual abuse among Malaysian paramedical students," Child Abuse Neglect 20(6): 487-492.

Anonymous. 1995. "Early marriage," Inter-African Committee on Traditional Practices Affecting the Health of Women and Children Newsletter, 17, 8 (April).

Anonymous. 2000. "Rape in South Africa, Uganda and Zambia," Reproductive Health Matters 8(16): 180.

Awusabo-Asare, K. and J.K. Anarfi. 1999. "Rethinking the circumstances surrounding the first sexual experience in the era of AIDS in Ghana," in The Continuing HIV/AIDS Epidemic in Africa, ed. I.O. Orubuloye, J.C. Caldwell and J. Ntozi. Canberra: Australian National University, pp. 9-18.

Balmer, D.H., E. Gikundi, M.C. Billingsley, F.G. Kihuho et al. 1997. "Adolescent knowledge, values, and coping strategies: Implications for health in sub-Saharan Africa," Journal of Adolescent Health 21: $33-38$.

Barker, Gary. 1993. "Research on AIDS: Knowledge, attitudes and practices among street youth," Children Worldwide 20(2-3): 41-42.

Bautista, P.F. 1989. "Young unwed mothers: Medical, psychosocial and demographic implications. Quezon City, Philippines, Management Communication Systems," Unpublished final report submitted to the UNDP/UNFPA/WHO/World Bank Special Programme of Research, Development and Research Training in Human Reproduction, Geneva.

Billings, Deborah L., Claudia Moreno, Celia Ramos, Deyanira Gonzalez de Leon, Ruben Ramirez et al. 2002. "Constructing access to legal abortion services in Mexico City," Reproductive Health Matters 10(19): 86-94.

Bohmer, Lisa and Edward Kirumira. 1997. Access to Reproductive Health Services: Participatory research with Ugandan adolescents. Final Report and Working Paper, Makerere University, Child Health and Development Centre and Pacific Institute for Women's Health.

Bott, Sarah and Shireen J. Jejeebhoy. 2003. "Adolescent sexual and reproductive health in South Asia: An overview of findings from the 2000 Mumbai Conference," in Towards Adulthood: Exploring the Sexual and Reproductive Health of Adolescents in South Asia, ed. Sarah Bott, Shireen Jejeebhoy, Iqbal Shah and Chander Puri. Geneva: World Health Organisation, pp. 3-30.

Boyer, D. and D. Fine. 1992. "Sexual abuse as a factor in adolescent pregnancy and child maltreatment," Family Planning Perspectives 24(1): 4-11, 19. 
Brown, Ann Denise, S.J. Jejeebhoy, I. Shah and K. Yount. 2001. "Sexual relations among young people in developing countries: Evidence from WHO case studies," Occasional Paper No 4, Department of Reproductive Health and Research, World Health Organisation, Geneva WHO/RHR/01.8.

Buga, Geoffrey, Daniel Amoko and David Ncaylyana. 1996. "Sexual behaviour, contraceptive practice and reproductive health among school adolescents in rural Transkei," South African Medical Journal 86: 523-552.

Caceres, Carlos F., B.V. Marin, E.S. Hudes, A.L. Reingold and A.M. Rosasco. 1997. "Young people and the structure of sexual risks in Lima," AIDS 11 (supplement 1): 567-577.

Cadelina, C. 1998. "Sexual behaviour and level of awareness of STDs: A survey among college students," Dumaguete City, Philippines, Department of Sociology/Anthropolgy, Silliman University of Chiclayo, Unpublished final report submitted to the UNDP/UNFPA/WHO/World Bank Special Programme of Research, Development and Research Training in Human Reproduction, Geneva.

Center for Reproductive Law and Policy (CRLP). 2002. Bringing Rights to Bear: An Analysis of the Work of UN Treaty Monitoring Bodies on Reproductive and Sexual Rights. New York: Centre for Reproductive Law and Policy.

Chapko, M.K., P. Somse, A.M. Kimball, R.V. Hawkins and M. Massanga. 1999. "Predictors of rape in the Central African Republic," Health Care for Women International 20: 71-79.

Cheng Yimin, Kang Baohua, Wang Tieyan, Han Xuejun et al. 2001. "Case-controlled study on relevant factors of adolescent sexual coercion in China," Contraception 64: 77-80.

Eggleston, E., J. Jackson and K. Hardee. 1999. "Sexual attitudes and behaviour among young adolescents in Jamaica," International Family Planning Perspectives 25(2): 78-84, 91.

Fraser, T. 2002. "Early sexual activity raises HIV risk for Trinidad and Tobago girls. Findings of teenage survey spur calls for key policy changes in light of HIV/AIDS," Washington, D.C., Population Reference Bureau.

Ganatra, Bela and Siddhi Hirve. 2002. "Induced abortions among adolescent women in rural Maharashtra, India," Reproductive Health Matters 10(19): 76-85.

Gangrade, K.D., R. Sooryamoorthy and D. Renjini. 1995. "Child rape: Facets of a heinous crime,” Social Change: Issues and Perspectives 25(2-3): 161-176.

George, Annie and Surinder Jaswal. 1995. "Understanding sexuality: An ethnographic study of poor women in Bombay, India," Women and AIDS Research Program Report Series, No. 12, Washington D.C., International Centre for Research on Women.

Glover, Evam Kofi, Angela Bannerman, Brian Wells Pence, Heidi Jones, Robert Miller, Eugene Weiss and Joana Nerquaye-Tetteh. 2003. "Sexual health experiences of adolescents in three Ghanian towns," International Family Planning Perspectives 29(1): 32-40.

Goldstein, D.M. 1994. "AIDS and women in Brazil: The emerging problem," Social Science and Medicine 39(7): 919-929.

Graitcer, P. and Z. Youssef. 1993. "Injury in Egypt: An analysis of injuries as a health problem," Washington, D.C. and Cairo, U.S. Agency for International Development and Ministry of Health.

Guedes, Alessandra, Sarah Bott, Ana Guezmes and Judith Helzner. 2002. "Gender-based violence, human rights, and the health sector: Lessons from Latin America," Health and Human Rights 2(1): 177-193.

Handwerker, W.P. 1993. "Gender power differences between parents and high-risk sexual behaviour by their children: AIDS/STD risk factors extend to a prior generation," Journal of Women's Health 2-3: 301-316.

Heise, L., M. Ellsberg and M. Gottemoeller. 1999. "Ending violence against women,” Population Reports Series L: Issues in World Health 11:1-43. 
Heise, L.L., K. Moore and N. Toubia. 1995. Sexual Coercion and Reproductive Health: A Focus on Research. New York: The Population Council.

Hof, C. and A. Richters. 1999. "Exploring intersections between teenage pregnancy and gender violence: Lessons from Zimbabwe," African Journal of Reproductive Health 3(1): 51-65.

Hulton, L.A., R. Cullen and S.W. Khalokho. 2000. "Perceptions of the risks of sexual activity and their consequences among Ugandan adolescents," Studies in Family Planning 31(1): 35-46.

Human Rights Watch. 1999. Crime or Custom? Violence Against Women in Pakistan. New York: Human Rights Watch.

Human Rights Watch. 2002a. Suffering in Silence: The Links between Human Rights Abuses and HIV Transmission to Girls in Zambia. New York: Human Rights Watch.

Human Rights Watch. 2002b. World Report 2002. New York: Human Rights Watch.

Instituto Nacional de Estadisticas y Censos (INEC), Ministerio de Salud (MINSA). 2001. Encuesta Nicaraguaense de Demografia y Salud. Managua, Ministerio de Salud.

Isarabhakdi, P. 1995. "Determinants of sexual behaviour that influence the risk of pregnancy and disease among rural Thai young adults," Nakorn Pathom, Thailand, Institute for Population and Social Research, Unpublished final report submitted to the UNDP/UNFPA/WHO/World Bank Special Programme of Research, Development and Research Training in Human Reproduction, Geneva.

Jewkes, R., C. Vundule, F. Maforah and E. Jordaan. 2001. "Relationship dynamics and adolescent pregnancy in South Africa," Social Science and Medicine 52: 733-744.

Jewkes, Rachel, Jonathan Levin, Nolwazi Mbananga and Debbie Bradshaw. 2002. "Rape of girls in South Africa," Lancet 359: 319-320.

Kaufman, C.E. and S.E. Stavrou. 2002. 'Bus fare, please': The economics of sex and gifts among adolescents in urban South Africa," Population Council Policy Research Division Working Paper No 166, New York.

Kgosidintsi, N. 1997. "Sexual behaviour and risk of HIV infection among adolescent females in Botswana," Gaborone, Botswana, National Institute of Development, Research and Documentation Unpublished final report submitted to the UNDP/UNFPA/WHO/World Bank Special Programme of Research, Development and Research Training in Human Reproduction, Geneva.

Khan, M.E., J.W. Townsend, R. Sinha and S. Lakhanpal. 1996. "Sexual violence within marriage," Seminar 447: 32-35.

Kim, S.R. 1998 "High school girls' knowledge and behaviour on sex," People and Development Challenges 5(9): 17-18.

Kwon Tai-Hwan, Jun Kwang and Cho Sung-nam. 1994. "Sexuality, contraception and abortion among unmarried adolescents and young adults: The case of Korea," Seoul, Republic of Korea, College of Social Sciences, Seoul National University, Unpublished final report submitted to the UNDP/UNFPA/WHO/World Bank Special Programme of Research, Development and Research Training in Human Reproduction, Geneva.

Luke, Nancy. 2003. "Age and economic asymmetries in the sexual relationships of adolescent girls in subSaharan Africa," Studies in Family Planning 34(2): 67-86.

Luke, Nancy and Kathleen Kurz. 2002. Cross-generational and Transactional Sexual Relations in SubSaharan Africa: Prevalence of Behaviour and Implications for Negotiating Safer Sexual Practices. Washington D.C.: ICRW and PSI.

Luster, T. and S. Small. 1997. "Sexual abuse and sexual risk-taking among sexually abused girls," Family Planning Perspectives 29(5): 204-211.

Marston, Cicely. 2003. "Narratives of heterosexual coercion among young men and women in Mexico City," Unpublished. 
McFarlane, C., J. Friedman, H. Goldberg and L. Morris. 1999. Reproductive Health Survey 1997. Atlanta, Georgia: Centres for Disease Control.

Meekers, D. and A. Calves. 1997. “'Main' girlfriends, girlfriends, marriage, and money: The social context of HIV risk behaviour in sub-Saharan Africa," Health Transition Review, Supplement to vol. 7: 361-375.

Mehra, S., R. Savithri, and L. Coutinho. 2002a. "Gender double standards and power imbalances: Adolescent partnerships in Delhi, India," Paper presented at the Asia-Pacific Social Science and Medicine Conference, Kunming, China, October.

Mehra, S., R. Savithri and L. Coutinho. 2002b. "Sexual behaviour among unmarried adolescents in Delhi, India: Opportunities despite parental controls," Paper presented at the IUSSP Regional Population Conference, Bangkok, June.

Mendez Ribas, J.M., S. Necchi and M. Schufer. 1995. "Risk awareness and sexual protection: Perceptions and behaviour among a sexually active population, Argentina," Buenos Aires, Argentina, Hospital Clinic, University of Buenos Aires, Unpublished final report submitted to the UNDP/UNFPA/WHO/World Bank Special Programme of Research, Development and Research Training in Human Reproduction, Geneva.

Mensch, Barbara and Cynthia Lloyd. 1998. "Gender differences in the schooling experiences of adolescents in low-income countries: The case of Kenya," Studies in Family Planning 29(2): 167-184.

Mensch, Barbara S., Judith Bruce and Margaret E. Greene. 1998. The Uncharted Passage: Girls'Adolescence in the Developing World. New York: The Population Council.

Mgalla, Z., D. Schapink and J.T. Boerma. 1998. "Protecting school girls against sexual exploitation: Development of a guardian programme in Tanzania," Unpublished.

Mirsky, Judith. 2003. Beyond victims and villains: Addressing sexual violence in the education sector. Panos Report No. 47. London: Panos Institute.

Mpangile, G.S., M.T. Leshabari and D.J. Kihwele. 1999. "Induced abortion in Dar es Salaam, Tanzania: The plight of adolescents," in Abortion in the Developing World, ed. Axel I. Mundigo and Cynthia Indriso. New Delhi: Vistaar Publications, pp. 387-403.

Mulugeta, E., M. Kassaye and Y. Berhane. 1998. "Prevalence and outcomes of sexual violence among high school students," Ethiopian Medical Journal 36: 167-174.

National Center for Injury Prevention and Control (NCIPC). 2000a. Dating Violence Fact Sheet. Atlanta, Georgia, National Center for Injury Prevention and Control, Centers for Disease Control and Prevention. Available online at: www.cdc.gov/ncipc/factsheets/datviol.htm.

National Center for Injury Prevention and Control (NCIPC). 2000b. Rape Fact Sheet. Atlanta, Georgia, National Center for Injury Prevention and Control, Centers for Disease Control and Prevention. Available online at: www.cdc.gov/ncipc/factsheets/rape.htm.

National Center for Injury Prevention and Control (NCIPC). 2003. Sexual Violence Facts. Atlanta, Georgia, National Center for Injury Prevention and Control, Centers for Disease Control and Prevention. Available online at: www.cdc.gov/ncipc/factsheets/svfacts.htm.

Nnko, Soori and Robert Pool. 1997. "Sexual discourse in the context of AIDS: Dominant themes on adolescent sexuality among primary school pupils in Magu district, Tanzania," Health Transition Review, Supplement 3 to vol. 7: 85-90.

Nnko, Soori, Betty Chiduo, Gabriel Mwaluko and Mark Urassa. 2001. "Pre-marital sexual behaviour among out-of-school adolescents: Motives, patterns and meaning attributed to sexual partnership in rural Tanzania," African Journal of Reproductive Health 5(3): 162-174. 
Obi, S.N., B.C. Ozuma and A.K. Onyebuchi. 2002. "Pregnancy in unmarried adolescents in Nigeria," International Journal of Gynaecology and Obstetrics 77: 157-159.

Omorodion, F.I. and O. Olusanya. 1998. "The social context of reported rape in Benin City, Nigeria," African Journal of Reproductive Health 2(2): 37-43.

Palestinian Human Rights Monitor. 2002. "Honor killing: The killing of women on the basis of family," The Palestinian Human Rights Monitor 6, 4 (August).

Pantelides, E.I. 1991. "Knowing the fertility situation of adolescents in Argentina, quantifying the phenomenon and describing its characteristics" and "Exploring the network/complex of factors that determine whether an adolescent will be a father or mother, Argentina," Buenos Aires, Argentina, Centre for Population Studies, Unpublished final report submitted to the UNDP/UNFPA/WHO/World Bank Special Programme of Research, Development and Research Training in Human Reproduction, Geneva.

Patel, Vikram and Gracy Andrew. 2001. "Gender, sexual abuse and risk behaviours in adolescents: A cross-sectional survey in schools in Goa," National Medical Journal of India 14(5): 263-267.

Population Reference Bureau. 2000. The World's Youth 2000. Washington, D.C.: Population Reference Bureau.

Raffaelli, M., R. Campos, A.P. Merritt, E. Siqueira, C.M. Antunes. R. Parker, M. Greco, D. Greco and N. Halsey. 1993. "Sexual practices and attitudes of street youth in Belo Horizonte, Brazil," Social Science and Medicine 37(5): 661-670.

RAINN. n.d. Statistical database and bibliography available online at: www.rainn.org/statistics.html. Washington, D.C., Rape, Abuse and Incest National Network (RAINN).

Ramakrishna, Jayashree, Mani Karott and Radha Srinivasa Murthy. 2003. "Experiences of sexual coercion among street boys in Bangalore, India," in Towards Adulthood: Exploring the Sexual and Reproductive Health of Adolescents in South Asia, ed. Sarah Bott, Shireen Jejeebhoy, Iqbal Shah and Chander Puri. Geneva: World Health Organisation, pp. 95-98.

Rodriguez-Lay, G. 1997. "Research about acceptability and effectiveness of family planning services for young people who belong to an educative system," Lima, Peru, Institute for Population Studies, Unpublished final report submitted to the UNDP/UNFPA/WHO/World Bank Special Programme of Research, Development and Research Training in Human Reproduction, Geneva.

Sathar, Zeba and Cynthia Lloyd. 1993. "Who gets primary schooling in Pakistan: Inequalities among and within families," Research Division Working Papers No. 52. New York, Population Council.

Schoen, Cathy, Karen Davis, Karen Scott Collins, Linda Greenberg, Catherine DesRoches and Melinda Abrams. 1997. The Commonwealth Fund survey of the health of adolescent girls. Available online at: http://www.cmwf.org

Schoen, Cathy, Karen Davis, Catherine DesRoches and Alexander Shekhdar. 2001. The health of adolescent boys: Commonwealth Fund survey findings. Available online at: http://www.cmwf.org

Shalhoub-Kevorkian, N. 2000. "Mapping and analysing the landscape of femicide in Palestinian society," Unpublished report submitted to UNIFEM.

Silberschmidt, M. and Vibeke Rasch. 2001. “Adolescent girls, illegal abortions and 'sugar-daddies' in Dar-esSalaam: Vulnerable victims and active social agents," Social Science and Medicine 52: 1815-1826.

Silva, T.K., S.L. Schensul, J. Schensul et al. 1997. "Youth and sexual risk in Sri Lanka," Women and AIDS Program Research Report Series, Phase II, No. 3, Washington, D.C., International Centre for Research on Women.

Slap, Gail B., L. Lot, Bin Huang, C.A. Daniyam et al. 2003. "Sexual behaviour of adolescents in Nigeria: Cross sectional survey of secondary school students," British Medical Journal 326: 15-18. 
Sodhi, Geeta and Manish Verma. 2003. "Sexual coercion amongst unmarried adolescents of an urban slum in India," in Towards Adulthood: Exploring the Sexual and Reproductive Health of Adolescents in South Asia, ed. Sarah Bott, Shireen Jejeebhoy, Iqbal Shah and Chander Puri. Geneva: World Health Organisation, pp. 91-94.

Somse, Pierre, Michael K. Chapko and Reginald V. Hawkins. 1993. "Multiple sexual partners: Results of a national HIV/AIDS survey in the Central African Republic," AIDS 7(4): 579-583.

Srinivasa Murthy, Radha and Mani Karott. 2003. "Sexuality and sexual behaviour: Perceptions of street boys in Bangalore," in Reproductive Health in India: New Evidence and Issues, ed. Michael Koenig, Shireen Jejeebhoy, John Cleland, and Bela Ganatra (forthcoming).

Stewart, L., A. Sebastini, G. Delgado and G. Lopez. 1996. "Consequences of sexual abuse of adolescents," Reproductive Health Matters 7: 129-134.

Stock, J.L., M.A. Bell, D.K. Boyer and F.A. Connell. 1997. "Adolescent pregnancy and sexual risk-taking among sexually abused girls," Family Planning Perspectives 29(5): 200-203, 227.

UNAIDS. 1999. Sex and Youth: Contextual Factors Affecting Risk for HIV/AIDS. Geneva: UNAIDS.

UNICEF. 2001. Early Marriage: Child spouses. Florence: Innocenti Research Centre.

UNICEF/UNAIDS/WHO. 2002. Young People and HIV/AIDS: Opportunity in Crisis. Geneva: UNAIDS.

United Nations ESCAP, Government of Japan, National Commission for Child Welfare and Development, Pakistan. 2001. Sexually Abused and Sexually Exploited Children and Youth in Pakistan: A Qualitative Assessment of their Health Needs and Available Services in Selected Provinces. Bangkok: UNESCAP.

Varga, C.A. 1997. "Sexual negotiation and decision-making in the midst of AIDS: Youth in KwaZulu-Natal, South Africa," Health Transmission Review 7(suppl. 3): 45-68.

Varga, Christine. 2001. "The forgotten fifty per cent: A review of sexual and reproductive health research and programs focused on boys and young men in sub-Saharan Africa," African Journal of Reproductive Health 5(3): 175-195.

Villanueva, M. 1992. “Pregnancy and reproductive health in students that attend night school,” Lima, Peru, Cayetano Heredia Peruvian University, Institute for Population Studies, Unpublished final report submitted to the UNDP/UNFPA/WHO/World Bank Special Programme of Research, Development and Research Training in Human Reproduction, Geneva.

Wood, K. and R. Jewkes. 1997. "Violence, rape, and sexual coercion: Everyday love in a South African township," Gender and Development 5(2): 41-46.

Wood, K. and R. Jewkes. 2001. “ 'Dangerous' love: Reflections on violence among Xhosa township youth,” in Changing Men in Southern Africa, ed. R. Morrell. Pietermaritzburg: University of Natal Press, pp. 317-336.

Wood, K., F. Maforah and R. Jewkes. 1996. "Sex, violence and constructions of love among Xhosa adolescents: Putting violence on the sexuality education agenda," Unpublished paper, Pretoria, CERSA Women's Health, Medical Research Council.

Wood, K., F. Maforah and R. Jewkes. 1998. “' 'He forced me to love him': Putting violence on adolescent sexual health agendas," Social Science and Medicine 47(2):233-242.

Worku, A. and M. Addisie. 2002. "Sexual violence among female high school students in Debark, North-west Ethiopia," East African Medical Journal 79(2): 96-99.

World Health Organisation (WHO). 2002. World Report on Violence and Health. Geneva: WHO.

Youri, Pat (ed.). 1994. "Female adolescent health and sexuality in Kenyan secondary schools: A survey report," AMREF unpublished report, Nairobi.

Zierler, S., L. Feingold, D. Laufer et al. 1991. "Adult survivors of childhood sexual abuse and subsequent risk of HIV infection," American Journal of Public Health 81(5): 572-575. 


\section{Appendix Table 1 \\ Magnitude of lifetime experience of forced sexual relations in adolescence among young females: Findings from surveys}

\begin{tabular}{|c|c|c|c|c|c|c|}
\hline Country & Site & Sample & Question posed & Age & $\begin{array}{l}\text { Ever } \\
\text { experienced } \\
\text { forced sex }\end{array}$ & Source \\
\hline Ethiopia & $\begin{array}{l}\text { Addis Ababa, } \\
\text { Western Shoa }\end{array}$ & 14 high schools & $\begin{array}{l}\text { Any non-consensual } \\
\text { penetration of the } \\
\text { vagina by force or } \\
\text { threat, or when victim } \\
\text { is incapable of giving } \\
\text { consent }\end{array}$ & $\begin{array}{l}12-23 \\
<16\end{array}$ & $\begin{array}{l}5 \\
8\end{array}$ & $\begin{array}{l}\text { Mulugeta, Kassaye } \\
\text { and Berhane } 1998\end{array}$ \\
\hline Ethiopia & $\begin{array}{l}\text { Debark Town, } \\
\text { north-west }\end{array}$ & $\begin{array}{l}\text { Students in } \\
\text { Class 9-11 }\end{array}$ & $\begin{array}{l}\text { Ever forced to have } \\
\text { sex; raped }\end{array}$ & $12-21$ & 9 & $\begin{array}{l}\text { Worku and Addisie } \\
2002\end{array}$ \\
\hline & & Apprentices & $\begin{array}{l}\text { Ever raped } \\
\text { Ever deceived, } \\
\text { drugged into sex } \\
\text { Ever forced }\end{array}$ & & $\begin{array}{r}5 \\
17 \\
18\end{array}$ & \\
\hline Nigeria & Plateau State & $\begin{array}{l}\text { Secondary } \\
\text { school }\end{array}$ & $\begin{array}{l}\text { Forced sexual } \\
\text { intercourse }\end{array}$ & $12-21$ & 11 & Slap et al. 2003 \\
\hline South Africa & $\begin{array}{l}\text { National } \\
\text { (Demographic } \\
\text { and Health } \\
\text { Survey) }\end{array}$ & $\begin{array}{l}\text { Nationally } \\
\text { representative } \\
\text { sample }\end{array}$ & $\begin{array}{l}\text { Forced to have sexual } \\
\text { intercourse against } \\
\text { their will by being } \\
\text { threatened, held down } \\
\text { or hurt in some way or } \\
\text { persuaded to have } \\
\text { sexual intercourse } \\
\text { when they did not } \\
\text { want it before the age } \\
\text { of } 15\end{array}$ & $\begin{array}{l}15-49 \\
15-19 \\
20-24\end{array}$ & $\begin{array}{l}1.6 \\
3.0 \\
2.0\end{array}$ & Jewkes et al. 2002 \\
\hline South Africa & $\begin{array}{l}\text { Cape Town } \\
\text { township and } \\
\text { informal } \\
\text { settlement }\end{array}$ & $\begin{array}{l}\text { Never pregnant, } \\
\text { sexually } \\
\text { experienced } \\
\text { matched }\end{array}$ & $\begin{array}{l}\text { Ever had sex against } \\
\text { their wish } \\
\text { Been raped }\end{array}$ & $<19$ & $\begin{array}{l}60 \\
9\end{array}$ & Jewkes et al. 2001 \\
\hline India & Goa & In school & $\begin{array}{l}\text { Have you experienced } \\
\ldots \text { in the past } 12 \\
\text { months: Someone } \\
\text { forcing you to have } \\
\text { sex with them }\end{array}$ & 16 & 6 & $\begin{array}{l}\text { Patel and Andrew } \\
2001\end{array}$ \\
\hline
\end{tabular}




\section{Appendix Table 1 (Contd.)}

\begin{tabular}{|c|c|c|c|c|c|c|}
\hline Country & Site & Sample & Question posed & Age & $\begin{array}{l}\text { Ever } \\
\text { experienced } \\
\text { forced sex }\end{array}$ & Source \\
\hline $\begin{array}{l}\text { Republic of } \\
\text { Korea }\end{array}$ & National & 64 high schools & $\begin{array}{l}\text { Forced sexual } \\
\text { intercourse }\end{array}$ & $16-18$ & 4 & Kim 1998 \\
\hline Barbados & National & $\begin{array}{l}\text { Population } \\
\text { based, } 20-45 \text {, } \\
\text { retrospective }\end{array}$ & $\begin{array}{l}\text { Sexual abuse by } \\
\text { parent, step-parent, } \\
\text { that included breast } \\
\text { or genital touching, } \\
\text { any sexual activity by } \\
\text { age } 16 \text { with partner } 5 \\
\text { or more years older, } \\
\text { rape by age } 20\end{array}$ & $20-45$ & 33 & Handwerker 1993 \\
\hline Jamaica & National & $\begin{array}{l}\text { Reproductive } \\
\text { Health Survey }\end{array}$ & $\begin{array}{l}\text { Ever forced to have } \\
\text { intercourse }\end{array}$ & $15-19$ & 26 & $\begin{array}{l}\text { McFarlane et al. } \\
1999\end{array}$ \\
\hline Colombia & National & $\begin{array}{l}\text { Demographic and } \\
\text { Health Survey }\end{array}$ & $\begin{array}{l}\text { Forced to have sexual } \\
\text { relations }\end{array}$ & $15-19$ & 3 & Stewart et al. 1996 \\
\hline \multirow[t]{2}{*}{ Peru } & Lima & $\begin{array}{l}\text { Mandatory } \\
\text { registration for } \\
\text { military service } \\
\text { card }\end{array}$ & $\begin{array}{l}\text { Forced to have sex, } \\
\text { violently or not }\end{array}$ & 17 & 9 & Caceres et al. 1997 \\
\hline & & $\begin{array}{l}\text { Registration for } \\
\text { eligibility } \\
\text { certificate for } \\
\text { jobs, higher } \\
\text { education }\end{array}$ & & $19-30$ & 26 & \\
\hline
\end{tabular}




\section{Appendix Table 2 \\ Experience of forced first sex among young females: \\ Findings from surveys}

\begin{tabular}{|c|c|c|c|c|c|c|}
\hline Country & Site & Sample & Question posed & Age & $\begin{array}{l}\text { First } \\
\text { sex was } \\
\text { forced }\end{array}$ & Source \\
\hline Ghana & 6 districts & $\begin{array}{l}\text { Community- } \\
\text { based, reporting } \\
\text { retrospectively }\end{array}$ & $\begin{array}{l}\text { Circumstances of first } \\
\text { sex: forced, raped, } \\
\text { enticed, deceived }\end{array}$ & $15+$ & 15 & $\begin{array}{l}\text { Awusabo-Asare and } \\
\text { Anarfi } 1999\end{array}$ \\
\hline South Africa & Transkei & $\begin{array}{l}\text { In school, Class } \\
5-7\end{array}$ & $\begin{array}{l}\text { Reason for first sex: } \\
\text { forced by partner }\end{array}$ & $13-17$ & 28 & $\begin{array}{l}\text { Buga, Amoko and } \\
\text { Ncaylyana } 1996\end{array}$ \\
\hline South Africa & $\begin{array}{l}\text { Cape Town } \\
\text { township and } \\
\text { informal } \\
\text { settlement }\end{array}$ & $\begin{array}{l}\text { Never pregnant, } \\
\text { sexually } \\
\text { experienced } \\
\text { matched }\end{array}$ & $\begin{array}{l}\text { First sex forced or } \\
\text { rape } \\
\text { "Persuaded" }\end{array}$ & $<19$ & $\begin{array}{l}18 \\
52\end{array}$ & Jewkes et al. 2001 \\
\hline South Africa & $\begin{array}{l}\text { Cape Town } \\
\text { township and } \\
\text { informal } \\
\text { settlement }\end{array}$ & $\begin{array}{l}\text { Not pregnant, } \\
\text { matched (with } \\
\text { pregnant) }\end{array}$ & $\begin{array}{l}\text { First sex forced or } \\
\text { rape } \\
\text { "Persuaded" }\end{array}$ & $<19$ & $\begin{array}{l}32 \\
42\end{array}$ & Jewkes et al. 2001 \\
\hline $\begin{array}{l}\text { Central African } \\
\text { Republic }\end{array}$ & National & $\begin{array}{l}\text { Population- } \\
\text { based }\end{array}$ & $\begin{array}{l}\text { First sexual encounter: } \\
\text { rape }\end{array}$ & $15-19$ & 24 & Chapko et al. 1999 \\
\hline $\begin{array}{l}\text { Central African } \\
\text { Republic }\end{array}$ & National & $\begin{array}{l}\text { Population- } \\
\text { based, } \\
\text { retrospective }\end{array}$ & $\begin{array}{l}\text { First sexual encounter: } \\
\text { rape }\end{array}$ & $15-50$ & 22 & $\begin{array}{l}\text { Somse, Chapko and } \\
\text { Hawkins } 1993\end{array}$ \\
\hline Kenya & National & $\begin{array}{l}\text { Secondary } \\
\text { school }\end{array}$ & $\begin{array}{l}\text { Encounter was forced } \\
\text { or "cheated" into } \\
\text { having sex }\end{array}$ & $12-24$ & 40 & Youri 1994 \\
\hline $\begin{array}{l}\text { Republic of } \\
\text { Korea }\end{array}$ & $\begin{array}{l}\text { EPZ employees, } \\
\text { in dormitories }\end{array}$ & Factories & $\begin{array}{l}\text { Reason for first sex: } \\
\text { forced by colleague or } \\
\text { supervisor }\end{array}$ & $19-29$ & 9 & $\begin{array}{l}\text { Kwon Tai-Hwan, Jun } \\
\text { Kwang and Cho Sung- } \\
\text { nam } 1994\end{array}$ \\
\hline Philippines & Dumaguete city & College students & $\begin{array}{l}\text { First sexual partner: } \\
\text { rape }\end{array}$ & $15-24$ & 5 & Cadelina 1998 \\
\hline Argentina & $\begin{array}{l}\text { Federal capital, } \\
\text { Chubut }\end{array}$ & $\begin{array}{l}\text { Reproductive } \\
\text { health facility: } \\
\text { seeking care }\end{array}$ & $\begin{array}{l}\text { Reason for first sex: } \\
\text { violacion }\end{array}$ & $13-19$ & 5 & Pantelides 1991 \\
\hline Argentina & Buenos Aires & $\begin{array}{l}\text { High-school } \\
\text { students }\end{array}$ & $\begin{array}{l}\text { Reason for first sex: } \\
\text { violacion }\end{array}$ & $14-20$ & 2 & $\begin{array}{l}\text { Mendez Ribas, Necchi } \\
\text { and Schufer } 1995\end{array}$ \\
\hline Peru & $\begin{array}{l}\text { Lima, Cusco, } \\
\text { Iquitos }\end{array}$ & $\begin{array}{l}\text { Secondary } \\
\text { school }\end{array}$ & $\begin{array}{l}\text { Reason for first sex: } \\
\text { forced by partner }\end{array}$ & $13-19$ & $\begin{array}{l}2- \\
20\end{array}$ & $\begin{array}{l}\text { Alarcon and Gonzales } \\
1996\end{array}$ \\
\hline Peru & $\begin{array}{l}\text { San Martin de } \\
\text { Porres }\end{array}$ & $\begin{array}{l}\text { Night-school } \\
\text { students }\end{array}$ & $\begin{array}{l}\text { Reason for first sex: } \\
\text { forced by partner }\end{array}$ & $10-19$ & 18 & Rodriquez-Lay 1997 \\
\hline Peru & Lima & $\begin{array}{l}\text { Night-school } \\
\text { students }\end{array}$ & $\begin{array}{l}\text { Reason for first sex: } \\
\text { forced by partner }\end{array}$ & $10-24$ & 41 & Villanueva 1992 \\
\hline
\end{tabular}




\section{Appendix Table 3 \\ Experience of forced sexual relations among sexually active, pregnant young females or recent mothers: Findings from surveys}

\begin{tabular}{|c|c|c|c|c|c|c|}
\hline Country & Site & Sample & Question posed & Age & $\begin{array}{l}\text { First } \\
\text { sex was } \\
\text { forced }\end{array}$ & Source \\
\hline Ethiopia & $\begin{array}{l}\text { Addis Ababa, } \\
\text { Western Shoa }\end{array}$ & $\begin{array}{l}\text { Sexually } \\
\text { experienced high } \\
\text { school students }\end{array}$ & $\begin{array}{l}\text { Any non-consensual } \\
\text { penetration of the } \\
\text { vagina by force or } \\
\text { threat, or when victim } \\
\text { is incapable of giving } \\
\text { consent }\end{array}$ & $12-23$ & 59 & $\begin{array}{l}\text { Mulugeta, Kassaye } \\
\text { and Berhane } 1998\end{array}$ \\
\hline Nigeria & Ibadan & $\begin{array}{l}\text { Sexually } \\
\text { experienced } \\
\text { students }\end{array}$ & Ever forced & $15-19$ & 48 & Ajuwon et al. 2001a \\
\hline & & Apprentices & & & 39 & \\
\hline Nigeria & Plateau State & $\begin{array}{l}\text { Sexually active } \\
\text { secondary school }\end{array}$ & $\begin{array}{l}\text { Forced sexual } \\
\text { intercourse }\end{array}$ & $12-21$ & 45 & Slap et al. 2003 \\
\hline South Africa & $\begin{array}{l}\text { Cape Town } \\
\text { township and } \\
\text { informal } \\
\text { settlement }\end{array}$ & $\begin{array}{l}\text { Pregnant, } \\
\text { matched (with } \\
\text { above) }\end{array}$ & $\begin{array}{l}\text { Ever had sex against } \\
\text { wish } \\
\text { Been raped }\end{array}$ & $<19$ & $\begin{array}{l}72 \\
11\end{array}$ & Jewkes et al. 2001 \\
\hline Philippines & Manila & $\begin{array}{l}\text { First time } \\
\text { mothers }\end{array}$ & $\begin{array}{l}\text { Reason for pregnancy: } \\
\text { forced }\end{array}$ & $15-24$ & 6 & Bautista 1989 \\
\hline Peru & Lima & $\begin{array}{l}\text { Mandatory } \\
\text { registration for } \\
\text { military service } \\
\text { card; sexually } \\
\text { active }\end{array}$ & $\begin{array}{l}\text { Forced to have sex, } \\
\text { violently or not }\end{array}$ & 17 & 57 & Caceres et al. 1997 \\
\hline
\end{tabular}




\section{Appendix Table 4}

\section{Magnitude of experience of forced sexual relations (life-time or at initiation) in adolescence among young males: Findings from surveys}

\begin{tabular}{|c|c|c|c|c|c|c|}
\hline Country & Site & Sample & Question posed & Age & Ever & Source \\
\hline $\begin{array}{l}\text { Central African } \\
\text { Republic }\end{array}$ & National & $\begin{array}{l}\text { Population-based, } \\
\text { retrospective }\end{array}$ & $\begin{array}{l}\text { First sexual encounter: } \\
\text { rape }\end{array}$ & $15-50$ & 7 & $\begin{array}{l}\text { Somse, Chapko and } \\
\text { Hawkins } 1993\end{array}$ \\
\hline Ghana & 6 districts & $\begin{array}{l}\text { Community-based, } \\
\text { reporting } \\
\text { retrospectively }\end{array}$ & $\begin{array}{l}\text { Circumstances of first } \\
\text { sex: forced, raped, } \\
\text { enticed, deceived }\end{array}$ & $15+$ & 10 & $\begin{array}{l}\text { Awusabo-Asare and } \\
\text { Anarfi } 1999\end{array}$ \\
\hline Nigeria & Ibadan & Students & $\begin{array}{l}\text { Ever raped } \\
\text { Deceived/drugged } \\
\text { Total forced }\end{array}$ & $15-19$ & $\begin{array}{l}4 \\
7 \\
9\end{array}$ & Ajuwon et al. 2001a \\
\hline & & Apprentices & $\begin{array}{l}\text { Ever raped } \\
\text { Deceived/drugged } \\
\text { Total forced }\end{array}$ & & $\begin{array}{l}1 \\
6 \\
7\end{array}$ & \\
\hline Nigeria & Plateau State & $\begin{array}{l}\text { Secondary school } \\
\text { all Sexually } \\
\text { experienced }\end{array}$ & $\begin{array}{l}\text { Forced sexual } \\
\text { intercourse }\end{array}$ & $12-21$ & $\begin{array}{l}14 \\
32\end{array}$ & Slap et al. 2003 \\
\hline South Africa & Transkei & $\begin{array}{l}\text { In school, Class } \\
5-7, \text { sexually } \\
\text { experienced }\end{array}$ & $\begin{array}{l}\text { Reason for first sex: } \\
\text { forced by partner }\end{array}$ & $14-18$ & 6 & $\begin{array}{l}\text { Buga, Amoko and } \\
\text { Ncaylyana } 1996\end{array}$ \\
\hline India & Goa & In school & $\begin{array}{l}\text { Have you experienced } \\
\ldots \text { in the past } 12 \\
\text { months: Someone } \\
\text { forcing you to have } \\
\text { sex with them }\end{array}$ & 16 & 7 & $\begin{array}{l}\text { Patel and Andrew } \\
2001\end{array}$ \\
\hline Philippines & Dumaguete city & College students & First sexual partner & $15-24$ & $<1$ & Cadelina 1998 \\
\hline Sri Lanka & & $\begin{array}{l}\text { Community-based: } \\
314 \text { young men }\end{array}$ & $\begin{array}{l}\text { Sexual intimacy with } \\
\text { an older male at age } 13 \\
\text { or less under coercion }\end{array}$ & & 7 & Silva et al. 1997 \\
\hline Barbados & National & $\begin{array}{l}\text { Population-based, } \\
20-45 \text {, } \\
\text { retrospective }\end{array}$ & $\begin{array}{l}\text { Sexual abuse by } \\
\text { parent, step-parent, } \\
\text { that included breast or } \\
\text { genital touching, any } \\
\text { sexual activity by age } \\
16 \text { with partner } 5 \\
\text { years older or more, } \\
\text { rape by age } 20\end{array}$ & $20-45$ & 2 & Handwerker 1993 \\
\hline Peru & $\begin{array}{l}\text { Lima, Cusco, } \\
\text { Iquitos }\end{array}$ & Secondary school & $\begin{array}{l}\text { Reason for first sex: } \\
\text { forced by partner }\end{array}$ & $13-19$ & $3-7$ & $\begin{array}{l}\text { Alarcon and } \\
\text { Gonzales } 1996\end{array}$ \\
\hline Peru & Lima & $\begin{array}{l}\text { Mandatory } \\
\text { registration for } \\
\text { military service card } \\
\text { Registration for } \\
\text { eligibility } \\
\text { certificate for jobs, } \\
\text { higher education }\end{array}$ & $\begin{array}{l}\text { Forced to have sex, } \\
\text { violently or not }\end{array}$ & $19-30$ & 20 & Caceres et al. 1997 \\
\hline
\end{tabular}


